\title{
The syntax and semantics of Swedish copular sentences: a comparative perspective
}

\section{Kajsa Djärv ${ }^{1}$}

Received: 28 April 2018 / Accepted: 16 January 2020 / Published online: 6 March 2021

(c) The Author(s) 2021

\begin{abstract}
This paper investigates the (recent) case alternation in Swedish equative and predicational copular sentences ('Cicero is Tully', 'Cicero is a nice guy'). A central contribution of the paper is showing that this alternation is an LF-phenomenon, contra Sigurðsson (in: Hartmann, Molnárfi (eds) Comparative studies in Germanic syntax: from Afrikaans to Zurich German. John Benjamins Publishing Company, Amsterdam, 2006) who conjectures that Swedish is changing in the direction of English and Danish, where all postcopular DPs receive Accusative case, regardless of interpretation. The Swedish alternation is shown to track the same semantic dimension that conditions the choice of predicate case in languages like Polish, Russian and Dutch, namely the distinction between stage and individual level predication. Interestingly, the Swedish alternation is also shown to share distributional properties with the predicate case alternations in these languages. To account for these observations, I propose that the morphological and semantic contrasts between the two alternants are mediated by a structural difference, such that Nominative case involves a biclausal structure, and Accusative a monoclausal structure. This paper further adds to the typological picture, showing that Swedish patterns like Polish, Russian and Dutch, but unlike English and Danish, not just in terms of equative and predicational sentences, but also in specificational copular sentences ('The fastest runner here is Lisa'). I argue that a particular kind of predicate inversion analysis is required to account for the Swedish type of specification.
\end{abstract}

Keywords Copular sentences · Predication - Case · Syntax-semantics interface · Swedish · Comparative syntax

Kajsa Djärv

kdjarv@sas.upenn.edu

1 Department of Linguistics, University of Konstanz, 78457 Konstanz, Germany 


\section{Introduction}

Since Russell (1919), it is commonplace to distinguish between a meaningful identitycopula (1a), and an essentially semantically vacuous copula of predication (1b). ${ }^{1}$

(1) a. $\left[\left[\mathbf{b e}_{E q}\right]\right]: \lambda \mathrm{x}_{e} \cdot \lambda \mathrm{y}_{e} \cdot \mathrm{y}=\mathrm{x}$, e.g., 'Cicero is Tully'.

b. [[be Pred $]]: \lambda \mathrm{P}_{<e, t>} \cdot \lambda \mathrm{x}_{e} \cdot \mathrm{P}(\mathrm{x})$, e.g., 'Cicero is a philosopher.'

In his seminal work, Higgins (1973/1979) distinguished between four types of copular sentences (2), all of which may be realised by the surface string 'DP1 be DP2'.

(2) a. Predicational: 'John is tall.', 'John is the tallest man here.'

b. Equative: 'The morning star is the evening star.', 'You are you.'

c. Specificational: 'The winner is Sue.', 'The tallest man here is John.'

d. Identificational: 'This is John.', 'That is a lovely garden.'

This paper investigates the syntactic and semantic properties associated with the alternation between Nominative and Accusative case on the postcopular DP in Swedish copular clauses (3). The alternation appears to be a relatively new phenomenon in Swedish, which has traditionally allowed only Nominative case on postcopular DPs (Maling and Sprouse 1995; Sigurðsson 2006). ${ }^{3}$

(3) Swedish (Sigurðsson 2013, 6)

I mitt nästa liv vill jag vara dig/du.

In my next life want I be.INF you.ACC/NOM

'I my next life I want to be you.'

The investigation has an essentially comparative focus. In Sect. 2, I compare Swedish predicational and equative copular clauses with data from a range of languages (primarily Polish, but also Russian, Dutch, English and Danish). This comparison is motivated by the observation that, despite appearing to have quite different systems,

\footnotetext{
${ }^{1}$ Relevant inflectional morphology is glossed using the following abbreviations: ACC Accusative, NOM Nominative, INST Instrumental, GEN Genitive, SG singular, PL plural, MASC masculine, FEM feminine, SUBJ subjunctive, IND indicative, DEF definite, INDEF indefinite, PRES present, PST past, INF infinitive, REL relative pronoun, REFL reflexive, TOP topic, FOC focus, ADV adverb, PRON pronominal copula.

2 Work following Higgins (1973/1979) has typically recognised the first three types of copular sentences. There is substantial disagreement among researchers as to whether further subdivisions are motivated (see Mikkelsen 2011 and references cited therein). For the purpose of this paper, I set Higgins's (1973/1979) identificational subtype to the side.

3 The Swedish data reported in this paper that are not from previous literature, are based on the judgements of 5 native speakers of the same northern Swedish dialect (three speakers in their 20s, one of whom is the author, and two speakers in their 50s). The Polish data is similarly based on the judgements of five speakers (from different parts of Poland; all native speakers living abroad (20-40 years old)). I have also consulted one Danish speaker, one Russian speaker, and one Dutch speaker, along with a number of English speakers. The Swedish data was collected using an informal forced choice task whereby the four consultants (see fn. 3) were presented with a set of sentences of the relevant type (DP1 be DP2.NOM/DP2.ACC). They were then asked to choose for each of the sentences which of the alternatives (DP2.NOM/DP2.ACC) they preferred. They were also given the alternative that both options were equally good. Any disagreement between the consultants is explicitly noted in the paper; see fn. 9 .
} 
the Swedish alternation not only shares a number of distributional properties with these other languages, but the distribution of the two variants is also shown to track the same interpretive dimension. ${ }^{4}$

Based on this data, I argue that the case alternation tracks an interpretive distinction, mediated by two distinct LFs, and is not purely a PF-phenomenon, contra Sigurðsson (2006), who hypothesises that Swedish is undergoing a change at PF, towards a system like that in English and Danish, where all postcopular DPs are marked with Accusative case, regardless of their interpretation. More specifically, the data indicates that the Swedish alternation is conditioned by the same semantic factors that condition the Nominative/Instrumental alternation in Polish (and to some extent also Russian and Dutch): sentences with Nominative case on DP2 are interpreted as equatives or as involving individual level predication, whereas sentences with Accusative case (Instrumental in Polish) are interpreted as involving stage level predication. This contrast is well-established in the Slavic literature (e.g., Matushansky 2000, 2008, 2010; Citko 2008), but has not been previously discussed in the context of Swedish. Furthermore, I show that the Swedish alternation also displays the same syntactic properties as the Polish alternation: as is again well known in the context of Slavic, Nominative postcopular DPs cannot undergo A-bar extraction (e.g., Matushansky 2000; Citko 2008). However, what has not been previously noted, for neither Swedish nor Polish, is that Nominative postcopular DPs also show 'non-local' properties with respect to binding.

Having shown that predicational and equative copular sentences in Swedish behave semantically and syntactically like those in Polish, I turn to previous analytical claims made in the context of the Slavic alternation, and identify some empirical issues inherent to these. As an alternative, I propose an analysis of the alternation-based primarily on the Swedish and Polish data, whereby the morphological, syntactic, and semantic contrasts are all mediated by the same underlying structural difference, proposing a biclausal analysis for Nominative DPs and a monoclausal analysis for Accusative DPs. In particular, I argue that that the postcopular DP in these sentences receive Nominative case via Agree with $\mathrm{T}^{o}$ inside a silent free relative clause, whereas Accusative case is assigned by a semantically inert Pred $^{o}$ head to its sister DP; a predicate of type $<e t>$. In Polish, this predicational case is realized as Instrumental. The presence or absence of this tensed clausal layer accounts for both the morpho-syntactic and the semantic properties associated with the alternation. Section 3 provides an interim summary.

In Sect. 4, I turn to specificational copular clauses, showing that also in this case does Swedish pattern with Polish, along with Dutch and Russian, but unlike Danish and English. In the former group of languages, the postcopular DP (DP2) is the subject, whereas in the latter group the initial DP (DP1) is the subject. ${ }^{5}$ I argue that a particular type of 'predicate inversion' analysis is needed to account for the Swedish type of specification, such that specification is derived from the same types of structures underlying predicational and equative sentences. However, I show that this cannot

\footnotetext{
4 As we will see below, this has important consequences for Slavic, as it means that the case alternation cannot be tied exclusively to the presence or absence of the pronominal copula, given that Swedish doesn't have a pronominal copula, but still shows the same type of alternation.

5 In what follows, I use the terms DP1 and DP2 simply as descriptive labels, referring to the surface position of the two DPs.
} 
simply be topicalization of the lower DP. I end my discussion with a note on some of the empirical challenges facing accounts attempting to provide a unified account of predicational, equative and specificational copular sentences in languages of the Swedish type.

\section{Predication and equation}

\subsection{Basic properties}

The basic characteristic of predicational copular sentences, as in (2a), is that they attribute some property, provided by the postcopular element, to the subject DP. In this respect, they are like non-copular sentences, with the difference that the property is provided exclusively by the post-verbal element (Higgins' 1973/1979 'predicate complement'), whereas the copula itself is essentially meaningless. The semantics of predicational copular sentences can thus be characterised in terms of Partee's (1986) family of DP types: the subject (DP1) is referential, of type $e$, and the complement (DP2) is predicational or property-denoting, a function of type $<e t>$. This is then different from equative copular sentences, as in (2b), where both DPs are referential, of type $e$. For this type of sentence, the basic intuition is that it equates the referents of the two arguments of the copula. Evidence for this type ambiguity of the postcopular DP comes from the fact that it can pronominalize either with the pronoun 'who' (4a), which must range over animate referents, or with the pronoun 'what' (4b), which must range over inanimate referents (Partee 1986).

(4) English (Partee 2010, 29)

a. Who is John? John is the president of the club.

(Equation)

b. What is John? John is the president of the club.

(Predication)

The obligatorily referential status of DP1 can be demonstrated by the fact that it only pronominalises like an individual, as shown in (5).

(5) English (Mikkelsen 2011, 1808)

[The guest of honor $]_{i}$ was happy, wasn't $\{\text { she/he/*it }\}_{i}$.

In Sect. 2.2.1, I examine in detail the semantic properties of these types of copular clauses in Swedish, comparing them to their counterparts in Polish, Dutch, Russian, Danish, and English. I demonstrate that the Swedish case-alternation tracks an interpretive distinction, such that Accusative postcopular DPs are interpreted as stage level predicates, and Nominative DPs as individual level predicates, or as involving equation of the two DPs. In Sect. 2.2.2, I turn to the syntactic properties associated with the case-alternation. 


\subsection{Data}

\subsubsection{Interpretation}

At a first glance, Swedish copular sentences look quite different from their Polish and Russian counterparts. First, unlike in these languages, Swedish has only one copular element, the verbal copula 'vara' (be), shown in (6).

(6) Swedish

Anna är glad/en glad person.

Anna is happy/a happy person

'Anna is happy/a happy person.'

Polish and Russian, on the other hand, have two types of copular elements, ${ }^{6}$ the pronominal copula 'to' (Polish)/'éto' (Russian), which is always uninflected, and the verbal copula 'być' (Polish)/'byt', (Russian).

The choice of case on the postcopular element correlates with the type of copula. In Polish pronominal copular sentences (7a), only Nominative is possible on DP2 (note that here, the verbal copula jest is entirely optional, in the sense that its presence has no interpretive effect). When there is only the verbal copula (7b), however, only Instrumental is possible on DP2.

(7) Polish (Adapted from Citko 2008, 268-273)
a. Jan to (jest) lekarz/*lekarz-em. Jan PRON is doctor.NOM/doctor-INST 'Jan is a doctor.'
b. Jan jest lekarz-em/*lekarz. Jan is doctor-INST/doctor.NOM 'Jan is a doctor.'

The distribution of the pronominal copula in Russian is more complex than in Polish. For the purpose of the comparison with Swedish, I focus on predicational sentences where the verbal copula is non-zero-i.e., in the past or future tense. In these contexts, both Nominative and Instrumental are possible on DP2, as shown in (8). ${ }^{7}$

(8) Russian (Matushansky 2000, 289)

Makarenko byl xorošim učitel-em / xorošij učitel.

Makarenko was good teacher-INST / good teacher.NOM

'Makarenko was a good teacher.'

\footnotetext{
6 For references on the pronominal and the verbal copula cross-linguistically, see for instance Rothstein (1986) on Polish, Eid (1983) on Arabic, Doron (1983) and Rapoport (1987) on Hebrew, Pereltsvaig (2001), Geist (2007) and Partee (2010) on Russian, and Adger and Ramchand (2003) on Scottish Gaelic.

7 For further discussion of the Russian copula, see Matushansky (2000, 2008); Geist (2007); Partee (1998, 2010) among many others. For the purpose of the comparison with Swedish, I set the questions of exactly where the pronominal copula is merged and what interpretive function it may fill aside, and focus on the semantic and structural contrasts associated with the case-alternation.
} 
Swedish, on the other hand, is traditionally taken to allow only Nominative case on post-couplar DPs. However, as noted by Sigurðsson, a subtype of Swedish couplar sentences - where "the predicative DP takes on the ROLE of the subject DP, rather than its IDENTITY" (Sigurðsson 2006, 34) allows both Nominative and Accusative case, as shown in (9). ${ }^{8}$ As (9) shows, there is variation among speakers as to whether Accusative is accepted here.

(9) Swedish ((9a)-(9c) are from Sigurðsson 2006, 34; (9d) is from Sigurðsson 2013, 6)

a. Om jag vore du/?dig...

if I were you.NOM/you.ACC

'If I were you...'

b. \%Jag låtsas inte vara dig.

I.NOM pretend not be you.ACC

'I'm not pretending to be you.'

c. \%Jag vill vara dig, $\mathrm{du}$ kan vara mig.

I.NOM want be you.ACC, you.NOM can be me.ACC

'I want to be you, you can be me.'

d. I mitt nästa liv vill jag vara dig/du.

in my next life want I be.INF you.ACC/you.NOM

'I my next life I want to be you.'

As noted by Maling and Sprouse (1995), the presence of Accusative case on postcopular DPs appears to be a rather recent development in Swedish. ${ }^{9,10}$ Sigurðsson (2006), who discusses this alternation in the context of Germanic, argues that it can be understood in terms of a split between those languages that assign Accusative to

\footnotetext{
8 Heycock (2012) refers to these as ASSUMED IDENTITY contexts. An anonymous reviewer points out that these kinds of sentences are known in the philosophical literature as 'counter-identicals'. Here, I refer to clauses involving this kind of role-interpretation as 'predicational', as they make reference to a property. I return to the exact nature of the semantic contrast associated with the alternation below (see especially the discussion above (16)).

9 Relevant to this point, is that I found variation among my older consultants (>age 50) in whether they accepted Accusative in these contexts, whereas my younger consultants (<age 30) consistently accepted both Nominative and Accusative here.

10 An anonymous reviewer points out that the Swedish judgements are not entirely straightforward to give, pointing to a quote by Maling and Sprouse $(1995,185)$ :

In fact, some of our consultants complained that our examples were among the most difficult sentences they had ever been asked to judge. In many cases our consultants reported free variation between nominative and accusative or merely a preference for one or the other....[A] strictly structural approach is poorly equipped to account for the type of judgements given by our Swedish and German consultants. This state of affairs requires further investigation, perhaps from variationist and functional perspectives as well.
}

I agree that a more complete picture of the alternation would benefit from an investigation in variationist or acquisitional terms. Given that the alternation appears to represent a change-in-progress, an analysis in terms of 'competing grammars' (e.g., Kroch 1989, 1994; Yang 2000) seems like a promising avenue for further work. The structural approach detailed here would provide a useful starting point for such an enterprise, detailing the type of grammar represented by the incoming system. 
all 'dependent arguments' (Predicate Nominative languages), and those that assign Accusative to all 'dependent DPs' (Predicate Accusative languages). Swedish, he claims, is changing from a Predicate Nominative grammar (like Icelandic, which allows only Nominative on postcopular DPs), to a Predicate Accusative grammar (like English and Danish, which allow only Accusative on postcopular DPs). He posits a similar trajectory for Dutch, although notes that the two languages differ somewhat with respect to the contexts where Accusative is possible (see discussion in footnote $11)$.

However, if this was an across-the-board morpho-syntactic change, as Sigurðsson (2006) suggests, we would expect that all postcopular DPs in Swedish should be eligible for Accusative case, regardless of their interpretation. However, this is not what we find. In Swedish, only Nominative is possible in equative sentences.

(10) Swedish

$\mathrm{Jag}$ är jag/*mig, och du är
I.NOM am I.NOM/me.ACC, and you.NOM are
du/*dig.
you.NOM/you.ACC
'I am me, and you are you.'

In this respect then, Swedish is similar to Polish, Russian, and Dutch, which all allow Accusative case on the postcopular element in predicational contexts, but allow only Nominative on the postcopular element in equatives:

(11) Dutch ((11b) is from Heycock 2012, 214)

a. Ik ben ik/*mij, en jij bent

I-NOM am I.NOM/me.ACC, and you.NOM are

$\mathrm{jij} / * \mathrm{jou}$.

you.NOM/you.ACC

'I am me, and you are you'

b. Als ik jou was zou ik meteen

if I.NOM you.ACC be.PST would I.NOM immediately

weggaan.

leave

'If I were you I would leave immediately.'

(12) Russian ((12a) is from Geist 2007, 90; (12b) is repeated from (8) above.)

a. Ciceron éto byl Tullij/*Tulli-em.

Cicero.NOM PRON was Tully.NOM/Tully-INST

'Cicero was Tully.'

b. Makarenko byl xorošim učitel-em / xorošij učitel.

Makarenko was good teacher-INST / good teacherNOM

'Makarenko was a good teacher.' 
(13) Polish (Adapted from Citko 2008, 272)
a. Doktor Jekyll to $\mathrm{Mr}$ Hyde. doctor Jekyll.NOM PRON mr.NOM Hyde
'Doctor Jekyll is Mr. Hyde.'
b. *Doktor Jekyll jest pan-em Hyde. doctor Jekyll.NOM is mr-INST Hyde
'Doctor Jekyll is Mr. Hyde.'

This is different from Danish and English, which do behave like Sigurðsson's Predicate Accusative languages. Here, all copular sentences mark DP2 with Accusative, regardless of their interpretation: both the equatives in (14a) and (15a), and the predicational sentences in (14b) and (15b), require Accusative.

(14) English

a. I am me/*I, and you are you.

b. If you were me/*I, you would leave immediately.

(15) Danish

a. Jeg er mig/*jeg, og du er I.NOM am me.ACC/I.NOM, and you.NOM is $\mathrm{dig} / * \mathrm{du}$. you.ACC/you.NOM

'I am me, and you are you.'

b. Hvis jeg var dig/*du ville jeg gå med if I.NOM was you.ACC/you.NOM wanted I.NOM go with det samme.

the same

'If I were you, I would leave immediately.'

This is unexpected on Sigurðsson's account, whereby the case-alternation is a pure PF-phenomenon, with no semantic import. Even more problematically, it turns out that for speakers who allow both Nominative and Accusative, within the contexts where either appears to be possible, it's not a matter of free variation or semantically unconditioned optionality. Instead, we find that the choice of case tracks interpretation: if the DP is interpreted as temporally bounded, contingent, or eventive, Accusative is preferred (16a), whereas if the DP is interpreted as invariant, intrinsic, or inherent, Nominative is preferred (16b).

(16) Swedish

a. Context: I'm an impersonator, and like to pose as other people:

På semestern var jag honom/\#han.

on vacation was I him.ACC/he.NOM

'On my holiday, I was him.'

b. Context: I believe in reincarnation. In my current life, I'm this person, but... 
I mitt förra liv var jag han/\#honom.

in my last life was I he.NOM/him.ACC

'In my last life, I was him.'

This contrast recalls that between 'stage level' predication and 'individual level' predication (Carlson 1977), which has in fact been argued to be what drives the choice of Instrumental vs. Nominative case on predicate DPs in Polish and Russian. ${ }^{11}$ As shown in (17) from Polish, Nominative case on DP2 is infelicitous with intrinsically stage level predicates. Here, Instrumental case on DP2 is the only option. (See also Matushansky 2000, 2008, 2010; Babyonyshev and Matushansky 2006, and Geist 2007, among others on Russian.)

(17) Polish (Citko 2008, 274)

a. \#Jan to (jest) zbieg / pasażer /

Jan PRON is fugitive.NOM / passenger.NOM /

przechodzień / widz.

pedestrian.NOM / spectator.NOM

'Jan is a fugitive/passenger/pedestrian/spectator.'

b. Jan jest zbiegi-em / pasażer-em / piesz-ym /

Jan is fugitive-INST / passenger-INST / pedestrian-INST /

widz-em.

spectator-INST

'Jan is a fugitive/passenger/pedestrian/spectator.'

Further evidence that this is the relevant distinction comes from Citko (2008), who shows that the use of (typically) stage level predicates with the pronominal copula and Nominative case on DP2 improves, if coerced into an individual level predicate (18a). She also points out that Nominative gives rise to-so called-'lifetime effects', which are associated with individual level predication (18b).

(18) Polish (Citko 2008, 274)

a. Jan to (jest) nasz najwierniejszy widz.

Jan PRON is our most.faithful spectator.NOM

'Jan is our most faithful spectator.'

b. Jan to był mój najlepszy przyjaciel.

Jan PRON was my best friend.NOM

'Jan was my best friend.' $\rightsquigarrow$ Jan is no longer alive.

Of course, since in Swedish only pronouns have morphological case, testing this hypothesis with a wider range of constructions and contexts is difficult. However, it

\footnotetext{
11 As pointed out by Citko (2008), the contrast cannot be taken to correspond to the predication/equation distinction, as suggested by Doron (1983), Rapoport (1987), Rothstein (1995), Babyonyshev and Matushansky (2006), Geist (2007), and Bondaruk (2014), among others. That is, if the pronominal copula was simply an equative copula, as in (1a), and the verbal copula a predicational one, as in (1b), then the fact that the two elements can co-occur (as we saw above) would be unexpected. Furthermore, it should be immediately clear that the majority of the sentences below involving the pronominal copula and Nominative case on DP2 (e.g., (7a)) cannot be understood as involving equation, in any real sense.
} 
does predict that the use of Accusative case should be limited, given that pronouns, like proper names, are typically non-eventive, and thus generally excluded from functioning as stage level predicates. In Polish, these elements typically receive Nominative case. However, as shown in (19a), proper names can be coerced to receive eventive readings, given appropriate context. An example of such a reading of a proper name is given in (19). ${ }^{12}$ Here, Instrumental case is the preferred choice.

(19) Polish

a. On jest dzisiaj prawdziwym Einstein-em.

he is today real Einstein-INST

'He is a real Einstein today.'

b. \#On to (jest) dzisiaj Einstein.

he PRON is today Einstein.NOM

'He is Einstein today.'

Similarly, the only contexts that I am aware of, in which pronouns can be felicitously interpreted with respect to some eventuality, are precisely the type of 'role' or 'assumed identity' contexts discussed in the context of example (9) above, which are ambiguous between contingent, or temporally bounded readings, as in (16a), and invariant, inherent, or intrinsic readings, as in (16b). And indeed, when presented with the types of disambiguating scenarios illustrated in (16), those of my consultants who accept both Nominative and Accusative in the sentences in (9) now show a clear preference for Accusative case in the former context, and for Nominative in the latter. $^{13}$

To summarise our discussion of the interpretive properties associated with the Nominative-Accusative alternation in Swedish, we have observed that (contra Sigurðsson 2006) it does not pattern with English and Danish, but rather, seems to be

12 See also Adger and Ramchand (2003), who observe a similar contrast with respect to the pronominal/verbal copula distinction in Scottish Gaelic.

13 Note that Dutch appears to differ from Swedish in terms of the distribution of Accusative case on DP2 in predicational contexts. As shown in (1), Accusative is obligatory in these contexts. This is unlike in Swedish where (at least for some speakers), Nominative is the preferred choice in the former sentence type, and both Nominative and Accusative appear to be equally good in the latter sentence type.

(1) Dutch
if I.NOM you.ACC/you.NOM be.PST would I.NOM immediately weggaan.
a. *Als ik jou/*jij was zou ik meteen
leave
'If I were you I would leave immediately.'
b. In mijn volgende leven wil ik jou/*jij zijn.
in my next life want I.NOM you.ACC/you.NOM be
'I my next life I want to be you.'

This may be due to a grammatical difference between the two languages. However, it is worth pointing out that there might be substantial inter-speaker variation also in Dutch, both in terms of age and dialect, as noted already for Swedish. Much more work is needed to investigate this before we can make strong statements about what aspects of the observed and apparent cross-linguistic variation is due to grammatical differences between the two languages at a more global level. 
tracking a semantic distinction, whereby Accusative is preferred when the predication is interpreted as temporally bounded, contingent, or eventive (stage level predication), whereas Nominative is preferred if the predication is interpreted as invariant, intrinsic, or inherent (equation or individual level predication). What appears to be free variation in 'role' or 'assumed identity' sentences is argued to be due to their ambiguity in this regard. Next, we turn to the syntactic properties associated with the alternation.

\subsubsection{Structure}

In Polish, extraction of Instrumental, but not Nominative, postcopular DP is possible, as shown in (20), adapted from Citko (2008).

(20) Polish

a. [Najlepsz-ym kandydat-em] $]_{i}$ wiem, że był Jan $\mathrm{t}_{i}$. best-INST candidate-INST know.1SG that was Jan.NOM $t$

'I know that John is the best candidate.'

b. *[Nauka o naturze $]_{i}$ wiem, że fizyka [study about nature].NOM know.1SG that physics.NOM to $\mathrm{t}_{i}$.

PRON $t$

'I know that physics is the study of nature.'

The same also holds of Russian. As Matushansky (2000) shows, only Instrumentalmarked predicates can undergo A-bar extraction. ${ }^{14,15}$

(21) Russian (Matushansky 2000, 290)

a. Kakim učitel-em byl Makarenko?

what teacher-INST was Makarenko?

'What kind of teacher was Makarenko?'

b. *Kakim učitel byl Makarenko?

what teacher.NOM was Makarenko?

'What kind of teacher was Makarenko?'

Interestingly, we find that also in Swedish is it possible to topicalize Accusative, but not Nominative postcopular DPs, as illustrated in (22).

(22) Swedish

$[\mathrm{Dig} / * \mathrm{du}]_{i} \quad$ vill jag inte vara $\mathrm{t}_{i}$.

you.ACC/you.NOM want I not be $t$

'I don't want to be you.'

\footnotetext{
14 Here, illustrated with wh-movement-however, Matushansky (2000) shows that the same holds also for scrambling, extraction from embedded clauses, and topicalization.

15 For the remainder of this comparison, I leave Russian to the side, given the range of further complexities associated with the Russian alternation.
} 
Citko (2008) in fact claims that in copular clauses of the form 'DP1.NOM be DP2.NOM', neither DP can move. She uses this as an argument to motivate an analysis of the Polish alternation as involving different functional heads, which she labels $\pi .{ }^{16}$ In verbal copular clauses, she assumes that $\pi$ assigns Instrumental case to its complement, which behaves in all respects like the direct object of a transitive verb. For pronominal copular sentences, on the other hand, she assumes that these are headed by a 'defective' $\pi$-head, similar to the head of a coordination structure, with "no independent syntactic features of their own, [such that, KD] their only role is to mediate a relationship between a specifier and a complement" (Citko 2008, 288). Along with Matushansky (2008, 2010) and Bondaruk (2014), Citko (2008) assumes that the way in which DP2 gets Nominative case in these structures, is through some form of Multiple Agree with $\mathrm{T}^{o}$ (as in Hiraiwa 2002). Similarly to the head of a coordinate phrase, she takes this defective $\pi$-head to block extraction of both of its arguments. The example in (23) is intended to illustrate this point.

(23) Polish (Citko 2008, 270)

a. $\mathrm{Kto}_{i} \quad$ chcesz, żeby $\mathrm{t}_{i}$ był twoim najlepsz-ym who.NOM want.1SG that.SUBJ was your best-INST przyjaciel-em? friend-INST?

'Who would you like to be your best friend?'

b. ${ }^{*} \mathrm{Co}_{i} \quad$ myślisz, że $\mathrm{t}_{i}$ to (jest) fizyka? what.NOM think.2SG that.IND PRON is physics.NOM?

'What do you think is physics?'

The sentences in (23) are problematic, however, as they fail to control for two confounds. First, it is well-attested that long-distance extraction from embedded indicative clauses, such as (23b), is generally degraded (e.g., Progovac 1993; Giorgi and Pianesi 1997; Antonenko 2010). However, Citko's (2008) examples of extraction from a clause with an Instrumental DP2 all use subjunctive complements, as in (23a), whereas her examples of extraction from a clause with a Nominative DP2 all use indicative complements, as in (23b). Second, (23b) sounds odd also in English, which has no ban on DP1 movement in copular clauses. This is likely due to discourse factors (compare with 'Which of these subjects do you think is physics?'). ${ }^{17}$ Controlling for these two factors, however, we find that extraction of Nominative, but not Instrumental DP2, leads to ungrammaticality $(24 a, b)$ - but that extraction of DP1 in sentences with a Nominative DP2 is indeed grammatical (24c).

(24) Polish

a. [Najlepsz-ym kandydat-em $]_{i}$ wiem, że był best-INST candidate-INST know.1SG that.IND was Jan $\mathrm{t}_{i}$.

Jan.NOM $t$

'I know that John is the best candidate.'

\footnotetext{
16 Not to be confused with $\pi$ as used in the context of person, number, and gender features.

17 Thanks Julie Legate and David Embick, p.c., for raising these two points.
} 
b. *[Nauka o naturze $]_{i}$ wiem, że fizyka.NOM [study about nature].NOM know.1SG that.IND physics.NOM to $\mathrm{t}_{i}$. PRON $t$

'I know that physics is the study of nature.'

c. [Którạ z tych ksiạzek] $]_{i}$ myślisz, że $\mathrm{t}_{i}$ to [which of these books].NOM think.2SG that.IND PRON fizyka? physics.NOM?

'Which of these books do you think is physics?'

Thus, Citko's analysis places too strong of a ban on movement, in that it predicts that neither DP should be able to move. An even bigger problem for this analysis is that it also predicts that A-movement of DP1 to Spec,TP should be impossible in these sentences, given that extraction from coordinate phrases is bad both with respect to A and A-bar movement, as shown in (25) (and importantly, does not improve with d-linking). ${ }^{18}$
a. *Maya ${ }_{i}$ can $\mathrm{t}_{i}$ and Lisa play football.
b. *Which class $_{i}$ did Maya take $\mathrm{t}_{i}$ and teach Linguistics?

However, a ban on A-movement is clearly incompatible with the structure of Polish pronominal copular sentences, given that DP1 appears above all sentence adverbs, modals and negation, as well as above the pronominal copula TO (which Citko 2008 takes to be merged in $\mathrm{T}^{o}$ ).

(26) Polish (Citko 2008, 291)

Waterloo to $\quad$ nie/naprawdę/mogło $\}$ było zwycięstwo.

Waterloo PRON \{not/indeed/could\} was victory

'Waterloo was $\{$ not/indeed/perhaps $\}$ victory.'

The same is clearly true for Swedish as well, as shown in (27).

(27) Swedish

a. $\operatorname{Vem}_{i}$ tror $\mathrm{du} \mathrm{t}_{i}$ var honom på Halloweenfesten. who think you was him.ACC on Halloween.party.DEF?

'Who do you think was him at the Halloween party?'

b. $\operatorname{Vem}_{i}$ tror du $\mathrm{t}_{i}$ var han i hans förra liv? who think you was he.NOM in his last life?

'Who do you think was him in his last life?'

Hence, we may conclude that in both languages, it is specifically Nominative postcopular DPs that are prohibited from A-bar extraction. Next, I present a new

18 Thanks to Julie Legate, p.c., for this observation. 
observation, namely that Nominative DP2 also differ from Accusative/Instrumental DP2, in both Swedish and Polish, with respect to binding.

As shown in (28), Polish has two third person singular possessive pronouns: reflexive 'swoja' (FEM)/'swoim' (MASC), used with local antecedents (28a), and 'jej' (FEM)/“jego’ (MASC), used elsewhere (28b).

(28) Polish

a. Iga lubi swojąi ${ }_{i} / * k$ (własną) siostrę.

Iga.NOM likes her (own) sister.ACC

'Iga likes her (own) sister.'

b. $\operatorname{Iga}_{i} \quad$ lubi $\mathrm{jej}_{k / * i}$ (*własną) siostrę.

Iga.NOM likes her (own) sister.ACC

'Iga likes her (someone else's) sister.'

In verbal copular sentences with an Instrumental DP2, the expected reflexive possessive ('swoim') is used when DP1 is the antecedent, as in (29a). In pronominal copular sentences with a Nominative DP2, however, only the non-local pronoun ('jego') is grammatical-even though DP1 is the antecedent, as shown in (29b).

(29) Polish

a. $\operatorname{Jan}_{i} \quad$ jest $\operatorname{swoim}_{i / * k} / *$ jego własny-m lekarz-em.

Jan.NOM is his own-INST doctor-INST

' $\operatorname{Jan}_{i}$ is his ${ }_{j / * k}$ own doctor.'

b. $\operatorname{Jan}_{i}$ to jego $_{i / * k} / *$ swoim własny lekarz.

Jan.NOM PRON his own.NOM doctor.NOM

' $\mathrm{Jan}_{i}$ is his ${ }_{i}$ own doctor.'

Similarly, we find that in Swedish, regular reflexives, which also require a local antecedent, are obligatorily marked with Accusative case, even in those cases where Nominative case would otherwise be available, as shown in (30). ${ }^{19}$

19 Also in Polish, only Instrumental case is possible on reflexive pronouns:

(1) Polish
Tylko próbuję być sobạ
only trying.1SG be REFL.INST
'I'm only trying to be myself.'

However, in Polish, there appears to be no way of forming a Nominative reflexive form. This is unlike in Swedish, where a Nominative reflexive form does exist.

(2) Swedish

\author{
Fastnade i ett fängelse jag själv byggt. \\ got.caught in a prison 1SG.NOM self built \\ 'Got caught in a prison that I had built myself.' \\ (http://viktklubb.aftonbladet.se/kampanj/artikel/22519933/hem)
}


(30) Swedish (Sigurðsson 2013, 10)

Jag försöker bara vara mig själv/*jag själv.
I try only be me.ACC REFL/I.NOM REFL
'I only try to be myself.'

To summarise this section, we observe for Swedish, as in Polish, that Accusative/Instru mental postcopular DPs behave as though there were ordinary direct objects of the copula, both with respect to movement and binding. Nominative postcopular DP, however, behave with respect to both movement and binding, like we expect a DP to behave when it is embedded inside certain types of embedded clauses, such as factive or relative clauses that are islands for movement. This insight will become central in our analysis, which we turn to next.

\subsection{Towards an analysis (part I)}

Above, I discussed Citko's coordination account, and saw that it places too strong of a ban on movement. Before moving on to the analytical alternative proposed here, let us first consider a different option, proposed by Matushansky (2010) to account for the Nominative-Instrumental alternation in Russian.

Like Citko (2008), Matushansky also argues that Nominative case is assigned through Multiple Agree with matrix $\mathrm{T}^{o}$, in the absence of a case-assigning head, such as Bowers' (1993) $\operatorname{Pred}^{o}$, or Citko's (2008) non-defective $\pi^{\circ}$. She follows Bailyn and Rubin (1991); Bailyn and Citko (1999); Pereltsvaig (2001), and Bailyn (2001, 2002), in analysing Instrumental case as being assigned by $\operatorname{Pred}^{o}$. However, she points out the following issue with analyses based on the absence or presence of PredP: if the semantic function of $\operatorname{Pred}^{o}$ is to convert its complement-a semantically saturated entity (of type $e$ ), into a predicate or property of type et, and the syntactic function of Pred $^{O}$ is to assign predicate case (Instrumental in Russian and Polish, Accusative in Swedish), then it is not clear how to account for the presence of Nominative case on the postcopular DP in clearly predicational contexts, such as (31) (a point also raised in footnote 11 above). ${ }^{20}$

Footnote 19 continued

The issue is also not the Nominative itself (a question raised by an anonymous reviewer). In fact, with a pronoun, Nominative would be the preferred option; see also (9).

(3) Jag försöker bara vara jag/??mig.

I try only be I.NOM/me.ACC

'I only try to be me.'

20 Note the Slavic practice of using an orthographic dash (and a phonological pause) in place of the copula when DP1 is 3rd person (thanks to an anonymous reviewer for pointing this out). 
(31) Russian (Matushansky's 2010 example (12))

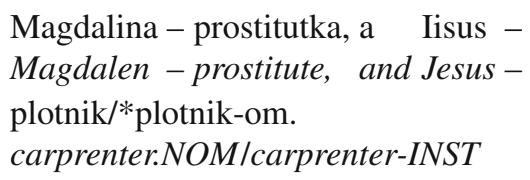

'Magdalen is a prostitute and Jesus is a carpenter.'

Matushansky's solution is to abandon a standard Agree-based analysis of caseassignment, and to adopt a view (argued for in more detail and on a more global level in Matushansky 2008), whereby case-assignment involves the copying of all the formal features of a head onto its sister domain - only some of which get spelled out at PF. Given the semantic function that she assumes Pred ${ }^{o}$ to fill, she takes it to be required also with Nominative DP2. In sentences with a Nominative DP2, however, she takes PredP to be selected directly by $\mathrm{T}^{o}$, whereas in copular sentences with Instrumental DP2, she takes PredP to be selected by an eventive $v \mathrm{P}$ (in turn, selected by $\mathrm{T}^{o}$ ), which introduces the verb's eventuality argument, and which assigns 'Eventive' case to its complement. For Matushansky (2010) then, it is the combination of the case features from $\mathrm{T}^{o}, v_{\text {evt }}^{o}$ and $\operatorname{Pred}^{o}$, that get spelled out as Instrumental, whereas the case features from $\mathrm{T}^{o}$ and $\operatorname{Pred}^{o}$ alone get spelled out as Nominative. An appealing aspect of this analysis is that it straightforwardly captures the correlation between the case on DP2 and its interpretation (eventive vs. non-eventive). However, as noted by Sigurðsson (2006) for a number of languages, including Swedish, Nominative case on DP2 does not depend on the presence of finite $\mathrm{T}^{o}$, as shown by the ECM-sentences in (32).

(32) Swedish (Sigurðsson 2006, 40)

Det räcker för mig att vara jag.

it suffices for me.ACC to be.INF I.NOM

'It's (good) enough for me to be me.'

Second, it is not clear how Matushansky's analysis, if applied to Swedish and Polish, would capture without further stipulation the syntactic differences between Nominative and Instrumental/Accusative copular sentences discussed in Sect. 2.2.2 above, repeated in Table 1 . That is, why would the fact that PredP is selected directly by $\mathrm{T}^{o}$ impose these types of restrictions on the movement and binding possibilities for the postcopular DP?

A final point to make in this section is that it is not simply the case that Swedish is currently undergoing a change in default case from Nominative to Accusative (as

Table 1 Summary of properties of Nominative and Instrumental/Accusative DP2

\begin{tabular}{|c|c|c|}
\hline Properties & Type I & Type II \\
\hline Case on DP2 & Nominative & Instrumental/Accusative \\
\hline Interpretation & $\begin{array}{l}\text { Invariant/intrinsic/ } \\
\text { inherent }\end{array}$ & $\begin{array}{l}\text { Temporally bounded/ } \\
\text { contingent/eventive }\end{array}$ \\
\hline Movement & No extraction allowed & Extraction allowed \\
\hline Binding & Non-local & Local \\
\hline
\end{tabular}


pointed out also in Maling and Sprouse 1995). The default case is stably Nominative, as illustrated in (33) (compare this with the translation showing that in English the default is Accusative).

\section{(33) Swedish}

Vem, jag/*mig??

who I.NOM/me.ACC??

Who, me??

Hence, appealing to an across-the-board change in default case will not work as an explanation for the availability of Accusative case on postcopular DPs. And again, it is not clear how such an explanation would capture any of the semantic and syntactic facts associated with the alternation.

Here, I want to consider a different analytical route, according to which the syntactic and semantic contrasts associated with the morphological case-alternation (Type I and Type II, in Table 1) are all mediated by the same structural difference. In particular, I suggest that the source of Nominative case on DP2 is a $\mathrm{T}^{o}$ head embedded inside a silent free relative clause, whereas 'predicate case' (Accusative or Instrumental, depending on the language ${ }^{21}$ ) is a non-structural (inherent) case, assigned by a predicational head to license its sister DP. ${ }^{22}$ This idea, illustrated in (34) (to be revised), has the advantage of straightforwardly capturing not just the morphological, but also the syntactic facts associated with the case-alternation-something which we have seen remains a challenge for previous accounts.

(34) Proposal (to be revised):

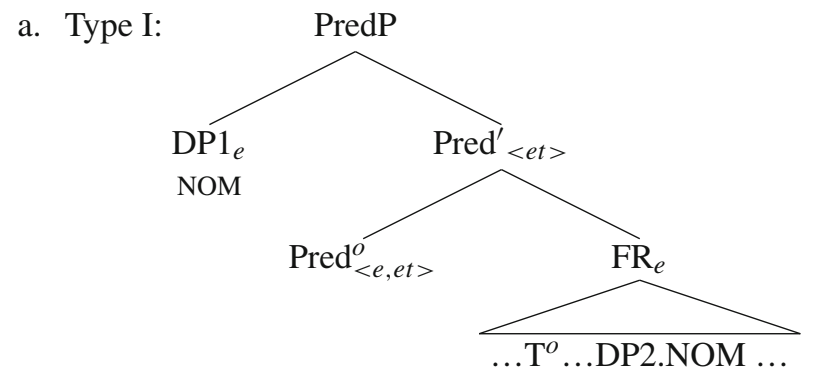

\footnotetext{
${ }^{21}$ Although note that its realisation is subject to further cross-linguistic variation. See for instance Matushansky (2012) on case in Finno-Ugric small clauses. An anonymous reviewer asks why Slavic lacks a similar Nominative-Accusative alternation, as these languages have Accusative elsewhere. The hypothesis advanced here is that the cases assigned by $v^{o}$ and Pred $^{\circ}$ are syncretic in the case-poor Germanic languages, whereas in the Slavic languages which have overall richer case-systems, the two cases have distinct morphological realisations.

22 The question of the connection between morphological case and argument licensing is a contentious one, with several authors arguing that the two are entirely independent (e.g., Marantz 1991; Sigurðsson 2012). Here I follow Vergnaud (1977/2008); Chomsky and Lasnik (1977); Pesetsky and Torrego (2004); Legate (2008); Deal (2009); Rezac (2013) among others, in assuming that DPs do need licensing via abstract case assignment in the syntax.
} 
b. Type II: PredP

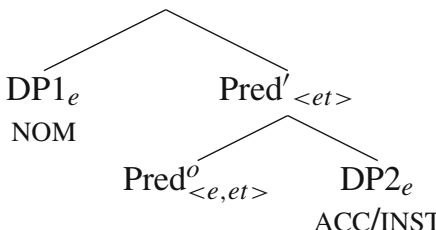

More precisely, the idea is that DP2 in a Type I copular clause is the subject of a free relative clause (such as 'I can help who's next in line'), as illustrated in (35), and as such, gets assigned Nominative case by this lower $\mathrm{T}^{o}$ head.

a. Han är $[F R$ REL du/*dig ÄR]. he is REL you.NOM/you.ACC are

'He is the individual who you are.'

b. Han är dig/*du.

he is you.ACC/you.NOM

'He is you.'

Type II

This has the syntactic consequence that a Type I DP2 is not local to its DP1, as it is merged inside the embedded relative clause. This is unlike DP2 in a Type II copular clause, which is local to its DP1 (the sister of $\operatorname{Pred}^{o}$, essentially a direct object). ${ }^{23}$ This contrast in locality then accounts for the binding facts discussed above. Regarding the movement facts, the hypothesis advanced here is that by being merged inside a free relative, DP2 in a Type I sentence is no longer available for extraction to the matrix clause, given that relative clauses are islands for extraction. This is unlike DP2 in a Type II clause, which is not subject to this kind of restriction.

Let us consider now the semantic consequences of this move. First, consider the role of $\operatorname{Pred}^{o}$. One option would be to take it to be present in both structures - as in (34). We then have to determine both what syntactic and semantic function this head fills. In the literature following Jacobson (1995), Caponigro (2003), and others, DPlike free relatives are typically analysed as CPs denoting maximal (atomic or plural) individuals of type $e$, such that maximalization applies directly to the set of individuals denoted by the TP, as shown schematically in (36). ${ }^{24,25}$ In (36), I follow Caponigro

\footnotetext{
23 Note that from this perspective, the Nominative-Accusative alternation in copular sentences finds precedence in analyses of phrasal comparatives (for discussion, see for instance Lechner 2001; Pancheva 2006, 2009; Bhatt and Takahashi 2011; Corver and Lechner 2014). As an anonymous reviewer points out, Swedish phrasal comparatives shows a similar contrast between Nominative and Accusative case (1), one which might plausibly be analysed as a contrast between a mono-clausal structure (Accusative; 'I'm taller than him') and a bi-clausal structure involving ellipsis (Nominative; 'I'm taller than he (is)').
}

(1) Jag är längre än han/honom.

I am taller than he.NOM/him.ACC

'I am taller than him'

A similar contrast is in fact also found in the Slavic languages; see Pancheva (2006, 2009).

24 Ignoring certain things such as the animacy-restriction on the wh-phrase, and semantically inert heads like $\mathrm{C}^{0}$.

25 I follow Kusumoto (1999) in my implementation of tense. 
(2003), who uses the $\delta$-operator (originally from Link's 1983 work on definite DPs) to apply to the set of entities denoted by the $\mathrm{CP}$, returning its maximal entity.

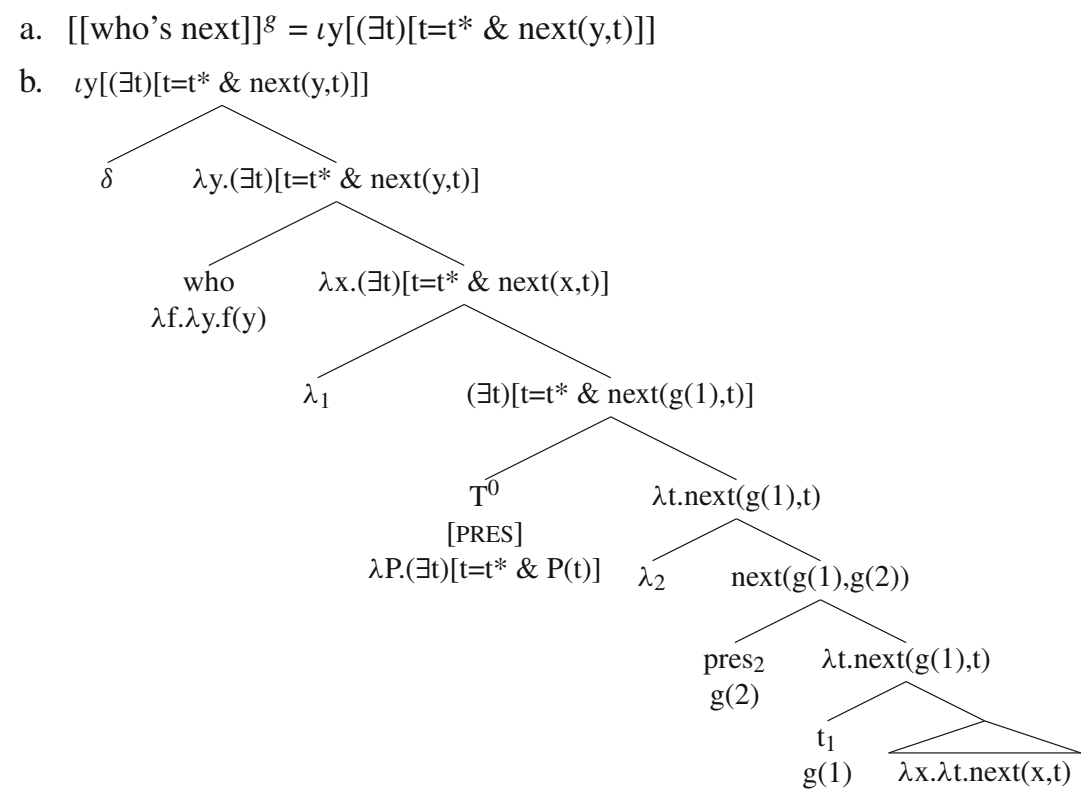

Hence, if the same type of predicational head is indeed present in both types of copular sentences, it should be of type $<e$,et $>$, as in (34). One possible denotation for this head would then be Partee's (1986) type-shifter IDENT, which takes a type $e$ argument and shifts it into an identity predicate, which is thus able to combine directly with the type $e$ subject.

$$
\begin{aligned}
& \text { a. IDENT[Clark Kent }]: \lambda y \cdot y=\text { Clark Kent } \\
& \text { b. IDENT[ } \iota x . f(x)]: \lambda y \cdot y=\iota x . f(x)
\end{aligned}
$$

regular individual type $e$ free relative; (36)

Note, however, that this move would force us to also analyse DPs like 'a teacher', 'the best dancer', etc. as individuals, rather than predicates, and to analyse sentences of the form 'DP1 be DP2.ACC' (e.g., (7b) and (8)) as identity predicates. This, however, would seem like an undesirable move, given that these DPs are clearly interpreted as stage level or eventive predicates.

Another, more promising, option would be to say that IDENT is not the meaning of $\operatorname{Pred}^{o}$, but rather an operator that applies directly to the free relative itself, similarly to Partee's (1986) original proposal. This then would no longer require us to analyse Accusative/Instrumental DPs as individuals - a welcome consequence. We can simply analyse these as predicates of type $<e t>$, and assume that Pred $^{o}$ itself is semantically vacuous (of type <et,et $>$ ), such that its only role is to license its predicate DP complement in the syntax. CPs, on the other hand, do not need case to be licensed, so $\operatorname{Pred}^{O}$ would never enter the derivation in a sentence involving a Nominative DP2 (SC stands for Small Clause). This option is illustrated in (38) (final version). 
(38)

a. Type I:

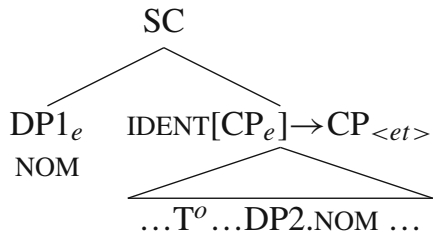

b. Type II:

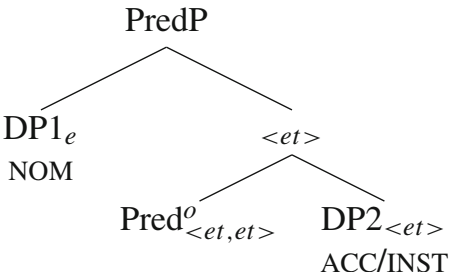

This then is similar, at least in spirit, to the proposals in Williams (1983) and Partee (1985, 1986), according to which there is only one type of copula or small clause head-a predicational head of type <et,et $>$ (as in (1b)), and equation is accomplished using Partee's type-shifter IDENT.

Analysing DPs like 'teacher', 'the best dancer', or 'a nice guy' as predicates is not unprecedented (e.g., Heggie 1988; Williams 1994; Moro 1997; cf. Higginbotham 1985 , 1987). However, this analysis raises the question of how to handle cases where an Accusative or Instrumental DP2 is a proper name or a pronoun, as these elements are not typically analysed as predicates. Here, I note that there is independent evidence indicating that there must be an accessible property (type $<e t>$ ) denotation at a subDP level, which does not depend on $\operatorname{Pred}^{\circ}$. This is illustrated by the availability of adjectival modification inside the DP, as in (19) above ('He's a real Einstein today.'), where there must be an available property meaning for the adjective to combine with. ${ }^{26}$ Further support for this claim comes from the fact that these kinds of uses of names are possible also in non-predicational contexts, such as 'This looks like it was written by a real Einstein', or 'Every young Mozart dreams of his first solo performance'. Here, I don't take a strong position on how these readings are derived; one alternative is to posit a PRED type-shifter, that applies directly to the name at sub-DP level, along the lines of (39) (though see also Saab and Lo Guercio 2020 and references therein for alternatives):

(39) $\lambda \mathrm{x}_{e} \cdot \lambda \mathrm{y}_{e} . l \pi . \pi$ is the unique contextually relevant distinguishing property associated with $\mathrm{x} \& \pi(\mathrm{y})$

This assumption, which is central to the current analysis, has the consequence that there is nothing special about predicational uses of DPs in copular constructions. ${ }^{27}$ The important point is that this observation offers independent support that Accusative/Instrumental marked pronouns and proper names have available predicate readings themselves, and are therefore able to combine with $\operatorname{Pred}^{o}$ in the same fashion as other DP predicates.

\footnotetext{
26 Thanks to Florian Schwarz, p.c., for this observation.

27 A question raised by this alternative is when this type-shifter may apply, as clearly DPs may also be interpreted as individuals, of type $e$.
} 
On the morpho-syntactic side, we saw the $\mathrm{T}^{o}$-head inside the silent free relative clause gives us Nominative case. However, as shown in (36), it also gives us a contrast in interpretation. (40)-(41) represent the consequences of combining the analysis in (38) with that in (36) for Nominative DP2, and with that in (39) for Accusative DP2. ${ }^{28}$

(40) Type I: Anna var du. (Anna was 2.SG.NOM)

a. $(\exists \mathrm{t})\left[\mathrm{t}<\mathrm{t}^{*} \&\right.$ Anna $=\iota \mathrm{x}\left[\left(\exists \mathrm{t}^{\prime}\right)\left[\mathrm{t}^{\prime}=\mathrm{t}^{*} \&\right.\right.$ ADDRESSEE $=\mathrm{x}$ at $\left.\left.\mathrm{t}^{\prime}\right]\right]$ at $\left.\mathrm{t}\right]$

b. Informally: At a time $t$ in the past, Anna was the unique individual $x$ that is identical to the addressee at the time which the sentence is about.

(41) Type II: Anna var dig. (Anna was 2.SG.ACC)

a. $(\exists \mathrm{t})\left[\mathrm{t}<\mathrm{t}^{*} \& \iota \pi . \pi\right.$ is the unique contextually relevant distinguishing property associated with ADDRESSEE \& $\pi$ (Anna) at $\mathrm{t}]$

b. Informally: At a time $t$ in the past, a unique property $\pi$ was associated with the addressee, and that property $\pi$ also holds of Anna at $t$.

That is, in Type II copular sentences, both DPs are bound by the matrix tense, as shown in (41), whereas in Type I sentences, the lower DP is bound by a separate, embedded, tense. This has the effect of fixing the referent of the Nominative DP2 at a particular, invariant, time; and then stating that the referent of DP1 is identical to that specific individual. For the Accusative DP2, on the other hand, the sentence simply ends up stating that whatever (relevant) property holds of that individual at the matrix time, that property also holds of the referent of DP1. I propose that this is what gives us the contrast in temporal or eventive (in)flexibility associated with the case-alternation, as discussed in Sect. 2.2.1 above.

Note, however, that on the current analysis as it presently stands, there is no way to distinguish between individual level predication and equation in structural or lexical terms. While this may seem like a potentially undesirable consequence, I submit that this is in fact not so. First, what I want to suggest is that this ambiguity of Nominative postcopular DPs may in fact fall out as a natural consequence from the familiar contrast between 'singular definite' and 'universal' readings of free relatives-a difference in intensionality (Jacobson 1995). The nature of this contrast is illustrated with the regular free relative in (42).

(42) I'll take [FR what he's having].

a. Singular Definite:

'I'll take the specific thing he's having.'

b. Universal:

'I'll take whatever it is he's having.'

For the denotation posited for Nominative DP2 (36), this would result in the following type of ambiguity, which seems to me appropriate for this contrast, though I leave it for future work to evaluate this hypothesis.

\footnotetext{
28 Note that this is not intended as a general claim about the semantics of individual and stage level predication, but specifically as a model of the interpretative contrast associated with the two types of post-copular DPs.
} 
(43) I want to be you.NOM.

a. Singular Definite $\approx$ equation:

'I want to be the specific individual you are.'

b. Universal $\approx$ individual level predication:

'I want to be whatever it is you are.'

Clearly a typology which takes individual and stage level predication to instantiate one grammatical type, distinct from equation, would fail to capture the fact that equation and individual level predicates pattern together morphologically and syntactically, at the exclusion of stage level predicates (see the summary in Table 1). An alternative would of course be to posit three distinct grammatical types: individual level predication, stage level predication, and equation. On this kind of analysis, however, the morphological and syntactic facts about equation and individual level predication would have to be accounted for independently for each sentence type. The current analysis captures not just these different facts, but also their coincidence. It also has two further advantages. Apart from delivering a simpler taxonomy and case correspondence, ${ }^{29}$ it also predicts that the case-alternation in a given language should correlate with the other grammatical and interpretive properties enumerated in Table 1, as they follow from the same underlying structures.

Note, finally, that this analysis also correctly predicts the absence of a casealternation along the stage vs. individual level dimension for AP and PP predicates. Given that these too are of type $<e t>$, and therefore compatible with Pred $^{o}$, we might at first sight expect that they should. However, given that these (like CPs) do not need to be externally licensed, $\operatorname{Pred}^{\circ}$ never enters the derivation with these predicates (and of course, there is no source of Nominative in this case).

\section{Interim summary}

The first point of Sect. 2 was to show that the Swedish case-alternation, given the associated interpretive and distributional facts, cannot be purely a PF phenomenon (contra Sigurðsson 2006). We then looked at comparative data, primarily from Polish, but also from English, Danish, Dutch and Russian, showing that Swedish predicational and equative copular clauses pattern with their counterparts in Polish (and to some extent apparently also Russian and Dutch). This data pointed to a typological generalisation regarding the way in which syntax mediates interpretation, whereby Swedish copular sentences follow the same strategy as in Polish, Russian and Dutch, unlike English and Danish. Finally, I proposed a theoretical account of the former type of strategy, whereby the alternation, and its syntactic and semantic correlates, are mediated by a structural difference.

In Sect. 4, I show that the typological split identified here runs deeper. Adding to the work of Mikkelsen (2002, 2004a, b, 2005, 2011); Geist (2007); Partee (2010); Heycock (2012), and others, I show that also specificational copular sentences in Swedish pattern with the former set of languages, and not with Danish and English-

29 As pointed out by an anonymous reviewer. 
thus making the typological generalisation a more broad-reaching one about how syntax, semantics, and information structure mediate interpretation.

\section{Specification}

In the first part of this section (Sect. 4.1), I review the basic linguistic properties of specificational copular sentences. Next, in Sect. 4.2, I give comparative data showing that, as we saw for predication and equation, Swedish specificational sentences behave like specificational sentences in Polish, Dutch and Russian, but unlike their counterparts in Danish and English, in terms of their morpho-syntactic properties. In Sect. 4.3, I argue that a particular type of predicate inversion analysis is needed to account for the Swedish type of pattern, whereby specification is derived from the same types of structures underlying predication and equation. However, this cannot simply be topicalization of the lower DP. I finish this section with a proposal for the derivation of specificational sentences in Swedish.

\subsection{Basic properties}

Specificational sentences are characterised in part by their particular semantic properties, such that DP1 (typically a definite description ${ }^{30}$ ) denotes a property containing a variable slot, which gets valued by the individual denoted by the postcopular DP (Partee 2010; Mikkelsen 2011). Evidence for the non-referential status of DP1 comes for instance from the fact that it pronominalises like a predicate, as shown in (44). ${ }^{31}$

(44) a. English

[The guest of honor $]_{i}$ was Lisa, wasn't $\{* \text { she/*he/it }\}_{i}$ ?

b. Swedish

$[\text { Hedersgästen }]_{i}$ var Lisa, visst var $\{* \text { hon/*han/det }\}_{i}$ ?

In this respect then, specificational copular sentences can be viewed as the inverse of predicational sentences, in that DP1 is of type <et $>$, and DP2 of type $e$ (see Heggie 1988; Moro 1997; Partee 1998; Mikkelsen 2005; den Dikken 2006, and Geist 2007).

However, this characterisation is not uncontroversial. As discussed originally by Heycock and Kroch (1999), the predicate must be able to be interpreted as being equated with the subject - that is, the two DPs have to be of the same semantic type, as shown by the contrast between (45a), involving two predicates, and (45a), involving a predicate and an argument.

(45) English (Heycock 2012, 225)

a. i. Honest is the one thing that I want a man to be.

ii. The one thing that I want a man to be is honest.

b. *The one thing that I want a man to be - honest - is John.

\footnotetext{
30 Although Heycock (2012) shows that the relevant distinction actually seems to be between strong and weak indefinites, such that DP1 in specificational copular sentences has to be at least a strong indefinite.

31 This is different from (5): 'The guest of honor was happy.', where the presence of an adjectival predicate forces a referential reading of DP1.
} 
This parallelism requirement appears to be a fairly robust generalisation, and is precisely the kind of observation that has motivated the analysis-originally due to Heycock and Kroch (1999), and pursued more recently by Heycock (2012), that specificational sentences are in fact a subtype of equatives (contra Heycock 1991; Moro 1997; Mikkelsen 2002, 2005; den Dikken 2006). See also Rothstein (2001); Heycock and Kroch (2002); Mikkelsen (2004b); Romero (2005); Comorovski (2007); and Heycock (2012) for arguments in favour of this characterisation. As shown in (46), this semantic parallelism requirement holds in Swedish as well. ${ }^{32}$

(46) Swedish

a. i. Ärlig är det enda jag vill att en man ska vara. honest is the single.thing I want that a man shall be 'Honest is the one thing that I want a man to be.'

ii. Det enda jag vill att en man ska vara är ärlig. the single.thing I want that a man shall be is honest The one thing that I want a man to be is honest.

b. *Det enda jag vill att en man ska vara-ärlig - är the single.thing I want that a man shall be - honest - is Johan. John

'*The one thing that I want a man to be - honest - is John.'

Another property characteristic of specificational sentences is their particular information structure. As noted by several authors (e.g., Mikkelsen 2004a, 2004b; Partee 2010; Heycock 2012), DP1 in these sentences must be a topic, whereas the postcopular DP is obligatorily focused, as shown by the sharp contrast between (47a) and (47b) (SMALL CAPS are used to indicate focus).

(47) English (Heycock 2012, 216-217)

a. Who was the culprit? (John or Bill?)

JOHN was the culprit. / The culprit was JOHN.

b. What was John? (Was John the culprit or the victim?)

John/he was the CULPRIT. / \#The CULPRIT was John.

\footnotetext{
32 Based on data like (1), Citko (2008) claims that in Polish, the two elements flanking the copula must be of the same syntactic category.
}

(1) Polish (Citko 2008, 267)
a. Droższe to nie zawsze lepsze. more-expensive PRON not always better
'More expensive is not always better.'
b. ??Droższe to nie luxury. more-expensive PRON not luxury
'More expensive isn't luxurious.'


Again, this is true of specification in Swedish as well. ${ }^{33}$

(48) Swedish

Q. Vem var bov-en? (Johan eller Ville?) who was culprit-DEF? (John or Bill?)

Who was the culprit? (John or Bill?)

A. JOHAN var bov-en. / Bov-en var JOHAN.

John was culprit-DEF / culprit-DEF was John

'JOHN was the culprit. / The culprit was JOHN.'

(49) Swedish

Q. Vad var Johan? (Var han offre-t eller bov-en?) what was John? (was he victim-DEF or culprit-DEF?)

'What was John? (Was John the culprit or the victim?)'

A. Johan/han var BOV-EN. /\#BOV-EN var Johan/han. John/he.NOM was culprit-DEF / culprit-DEF was John/he.NOM

'John/he was the CULPRIT. / \#The CULPRIT was John.'

\subsection{Two types of languages}

As discussed by Heycock (2012), some languages that allow Accusative case on postcopular DPs in predicational sentences, such as Dutch, nevertheless allow only Nominative case on DP2 in specificational sentences, as illustrated with the contrast between the specificational sentence in (50a), and the predicational sentence in (50b), repeated from (11b) above.

(50) Dutch (Heycock 2012, 214-215)

a. Het enige slachtoffer hierin bent the only victim herein be.PRES.2SG 2SG.NOM

'The only victim in this is you.'

b. Als ik jou was zou ik meteen weggaan.

if I.NOM you.ACC be.PST would I immediately leave

'If I were you I would leave immediately.'

The same is also true of Swedish, Polish and Russian: first, contrast the Swedish specificational sentences in (51) with the predicational ones in (52) (repeated from (9)), where both Nominative and Accusative are available.

\footnotetext{
33 Another property associated with specificational copular sentences, is what is typically referred to as 'connectivity effects', as observed for instance in the following sentence from Partee (1985): 'What Harvey ${ }_{i}$ did next was wash himself $i$ properly.' A discussion of these effects is unfortunately beyond the present scope, and I will set these aside for the remainder of this paper. For discussion, see Mikkelsen (2011) and references cited therein.
} 
(51) Swedish

a. Den bästa spelaren i laget är inte jag/*mig

the best player in team.DEF is not I.NOM/*me.ACC

(-det är du).

(-it is you.NOM)

'The best player on the team isn't me (- it's you).'

b. i. Vem är det lilla barnet på bilden?

'Who's that little child on the picture?'

ii. Det där lilla barnet på bilden, det är that there little child in picture.DEF, it is $\mathrm{jag} / *$ mig.

I.NOM/me.ACC

'That little child in the picture, that's me.'

(52) Swedish

a. Om jag vore du/?dig...

if I were you.NOM/you.ACC

'If I were you...'

b. \%Jag låtsas inte vara dig.

I.NOM pretend not be you.ACC

'I'm not pretending to be you.'

c. \%Jag vill vara dig, du kan vara mig.

I.NOM want be you.ACC, you.NOM can be me.ACC

'I want to be you, you can be me.'

d. I mitt nästa liv vill jag vara dig/du.

in my next life want I.NOM be.INF you.ACC/you.NOM

'I my next life I want to be you.'

Unlike the predicational sentences we looked at in the previous section, specificational sentences in Russian and Polish also allow only Nominative case on DP2, as shown in (53) and (54). ${ }^{34}$ The DP1 predicate however, can be either Nominative or Accusative (I return to this point shortly).

(53) Russian (Partee 2010, 28,30)

a. Vladelec-em ètogo osobnjaka byl juvelir owner-INST this.GEN mansion.GEN was jeweler.NOM

Fužere.

Fuzhere

'The owner of this mansion is the jeweler Fushere.'

\footnotetext{
34 Note that Russian specificational sentences do not allow the pronominal copula 'èto' (Geist 2007; Partee 2010), unlike in Polish. Again, we leave the question of the exact nature of the pronominal copula to the side for the purpose of this discussion. 
b. Vladelec ètogo osobnjaka - juvelir Fužere. owner.NOM this.GEN mansion.GEN - jeweler.NOM Fuzhere

'The owner of this mansion is the jeweler Fushere.'

(54) Polish [Context: Who is your best friend - Jan or Erik?]

a. Móim najlepszym przyjaciel-em jest Jan.

[my best friend]-INST is Jan.NOM

'My best friend is Jan.'

b. Moj najlepszy przyjaciel to Jan.

[my best friend].NOM PRON Jan.NOM

'My best friend is Jan.'

Furthermore, verbal agreement in Dutch, Polish and Russian is with the Nominative DP2 in specificational sentences, and with the Nominative DP1 in predicational sentences. This is important as agreement provides an independent test for which of the two DPs is the underlying subject, in the sense of standing in an Agree relation with the $\mathrm{T}^{o}$ head of the clause (e.g., Chomsky 2000, 2001). I will use this property to point to a typological split between languages where the Nominative DPl in specificational sentences is the subject, e.g., Danish and English (see also Mikkelsen 2004b and Partee 2010) and languages where the Nominative DP2 in specificational sentences is the subject (and DP1 is an inverted predicate), e.g., Polish, Russian, Swedish, and Dutch (see also Moro 1997, 28 for evidence that Italian is of the latter type). ${ }^{35}$ In predicational and equative sentences on the other hand, DP1 is the subject in both types of languages.

This is demonstrated for Dutch, with the contrast between the specificational sentence in (55a) and the predicational one in (55b). The sentences in (56)-(57) further show that the same is true in Russian and Polish: agreement in specificational sentences is with the obligatorily Nominative DP2.

(55) Dutch

a. Het enige slachtoffer hierin bent jij. the only victim herein be.PRES.2SG 2SG.NOM 'The only victim in this is you.'

b. Als zij jou waren, zouden zij weten hoe het if 3PL.NOM 2SG.ACC were.PL, would they know how it is om student te zijn. is to student to be

'If they were you, they would know what it's like to be a student.'

(56) Polish
a. Przyczynạ
wypadku byłi
Kamil
cause.3SG.FEM.INST accident.GEN were.3PL.MASC [Kamil
i Michał.
and Michat].PL.MASC.NOM

\footnotetext{
35 See also Hartmann and Heycock (2017) on agreement in Insular Scandinavian copular clauses.
} 
'The cause of the accident was Kamil and Michał.'

b. Największy drań u nas w pracy to napewno biggest jerk.MASC.NOM at us in work PRON definitely była Basia. was.FEM Basia.FEM.NOM

'The biggest jerk at our work is definitely Basia.' 36

(57) Russian (Geist 2007, 95, from Padučeva and Uspenskij 1997, 178)

a. Pričinoj avarii *byla/byli reason.SG.FEM.INST of.accident was.SG.FEM/were.PL neispravnye tormoza.

broken brakes.PL

'The reason for the accident was broken brakes.'

b. Edinstvennyj, kto vstal na našu storonu, only.person.MASC.NOM who came to our side *byl/byla Varvara was.MASC/was.FEM Barbara.FEM

'The only person who defended us was Barbara.'

Taken together with the agreement facts, the fact that DP1 in these sentences allow both Instrumental and Nominative case provides strong indication that DP1 is a predicate, whereas DP2 is the subject. ${ }^{37}$ Moreover, in (56a), the natural choice of case on DP1 is Instrumental, whereas in (56b), the natural choice is Nominative. This is what we would expect if DP1 in specification is underlyingly the same as DP2 in predicational sentences at some stage in the derivation, given the semantic conditions on the case-alternation (discussed in Sect. 2).

Predicational sentences, on the other hand, which allow both Instrumental and Nominative case on DP2, but only Nominative on DP1, obligatorily show DP1 agreement, as shown in (58)-(59) (contra claims by Bondaruk 2014 and Geist 2007).

(58) Polish (Citko 2008, 266, fn. 4)

$$
\begin{aligned}
& \text { Jan to był straszna świnia. } \\
& \text { Jan.MASC PRON was.MASC terrible.FEM pig.NOM.FEM }
\end{aligned}
$$

'Jan was a real bastard.'

\footnotetext{
36 It's worth noting that omitting the verbal copula altogether is generally preferred in pronominal copular sentences. Hence, some speakers also find the sentence in (56b) somewhat degraded. However, this is in clear contrast to the striking ungrammaticality of the same sentence with 'był' (MASC), instead of 'była' (FEM).

37 Since only pronouns are case-marked in Swedish and Dutch, it is unfortunately not possible to detect the case-alternation on DP1 in specificational sentences, given that pronouns cannot function as definite descriptions - and the one pronoun that would be possible here, the neuter pronoun 'det' (it), does not show case distinctions.
} 
(59) Russian

Anna byla/*byl xorošim učitel-em / xorošij

Anna was.FEM/was.MASC good teacher-INST.MASC / good

učitel.

teacher.NOM.MASC

'Anna was a good teacher.'

Note that Citko (2008) argues, from the example in (60) that-unlike in Russian (see Geist 2007, Partee 2010)—specificational sentences in Polish can only be formed using pronominal copular sentences with Nominative case on DP1, given that (60) can only be interpreted as 'my best friend is impersonating, or trying to be Jan', which is not a specificational interpretation. ${ }^{38}$

(60) Polish (Citko 2008, 272)

\#Mój najlepszy przyjaciel jest Jan-em.

my best friend.NOM is Jan-INST

'My best friend is Jan.'

Of course, this is precisely the kind of 'assumed identity' reading discussed in Sect. 2.2.1. That is, given that Instrumental case on DP2 is associated with a property reading, the only interpretation consistent with Instrumental case on proper names and pronouns, are precisely assumed identity readings. ${ }^{39}$ However, the sentences in (54) have the particular semantic and pragmatic properties associated with specificational sentences: (i) DP1 provides a description with a variable slot, which gets valued by the referent of the postcopular DP, and (ii) DP2 is focused, as indicated by the preceding question. In fact, it turns out that a specificational (focused DP2) reading is the only reading available for this kind of sentence, as shown by the fact that in a context which makes DP2 topical, the sentences in (54a,b) are both infelicitous, as shown in (61).

(61) Polish

Tell me something about Jan - who is he?

a. \#Móim najlepsz-ym przyjaciel-em jest Jan.

[my best-INST friend-INST] is Jan.NOM

'My best friend is Jan.'

b. \#Moj najlepszy przyjaciel to Jan.

[my best friend].NOM PRON Jan.NOM

'My best friend is Jan.'

Furthermore, recall, that DP1 in specificational sentences must be either a definite or a strong indefinite. As Citko (2008) points out, indefinites are typically bad in Polish sentences of this form (as in English, as shown by the translation in (62)).

\footnotetext{
38 Citko (2008) recognises that Polish has sentences of at least the kind in (54a), but she takes them to involve some other form of inversion. However, as I show in (61) below, a specificational reading appears to be the only available interpretation for this kind of sentence.

39 Or in the case of (19)—-metaphorical or property-readings of names, i.e., where 'Einstein' is taken to mean 'a real genius' (given that this is typically the contextually relevant property associated with Einstein; see (39)).
} 
(62) Polish (Citko 2008, 81)

*Lekarz to (jest) Jan.

doctor.INDEF PRON is Jan.NOM

'*A doctor is Jan.'

Altogether, this pattern is strikingly different from what we find in English and Danish, which as we saw above only allow Accusative case on the postcopular DP in equative and predicational sentences. These languages also permit only Accusative case on the postcopular DP in specificational sentences, as shown in the Danish example in (63) from Mikkelsen (2004b), and its English translation.

(63) Danish (Mikkelsen 2004b, 31)

Den højeste spiller på holdet er ikke hende/*hun.

the tallest player on team.DEF is not her.ACC/she.NOM

'The tallest player on the team isn't her/*she.'

Moreover, in English, agreement is always with DP1, in all types of copular sentences, as shown in (64).

(64) English

a. The best player on the team is/*are you, isn't it?

b. You are/*is the best player on the team, aren't you?

c. In an alternative life, you are/*is him.

Neither Swedish nor Danish show verb agreement. However, given the assumption that case is tied to agreement (Accusative assigned via Agree with $v^{o}$ and Nominative assigned via Agree with finite $\mathrm{T}^{o}$, a standard assumption following Chomsky 2000, $2001^{40}$ ), we may conclude that in Swedish specificational sentences, as in Dutch, Russian and Polish, DP2 is the grammatical subject. For Danish on the other hand, as in English, DP1 is the subject of specificational sentences-a conclusion defended also by Mikkelsen (2004b) and Partee (2010) (see also Geist 2007). This is illustrated in (65)-(66) below. In the following, I focus on the Swedish type (65), referring the reader to Mikkelsen (2004a, 2004b, 2005) for a discussion of Danish, and Heggie (1988), Heycock (1991, 2012), Heycock and Kroch (1999, 2002), Rothstein (2001), den Dikken (2006), and Partee (2010), among several others, on English.

\subsection{Towards an analysis (part II)}

Above, I argued that in specificational sentences in Swedish, Polish, Russian, and Dutch, DP2 is the subject, whereas in Danish and English, DP1 is the subject. Thus, I take it that in order to account for specification in the former set of languages,

40 Note that more recent work (Legate 2014) has argued that it is Voice ${ }^{o}$, rather than $v^{o}$ that is responsible for structural Accusative case. However, this question is orthogonal to the current discussion. It is also worth noting that a number of authors have argued against any link between case and agreement; see for instance Marantz (1991); McFadden (2004); Preminger (2014). 
some kind of inversion analysis is called for, unlike in the latter set (see Moro 1997; Geist 2007; Partee 2010; Heycock 2012; and references above). This is illustrated in (65)-(66); see Sect. 2.3 on SC and PredP.

(65) Specification: Swedish, Polish, Russian, and Dutch (to be revised)

a. Type I (Nominative DP1)

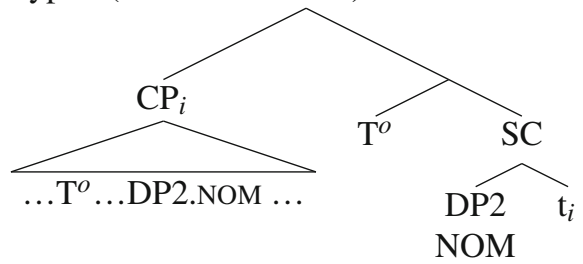

b. Type II (Instrumental/Accusative DP1)

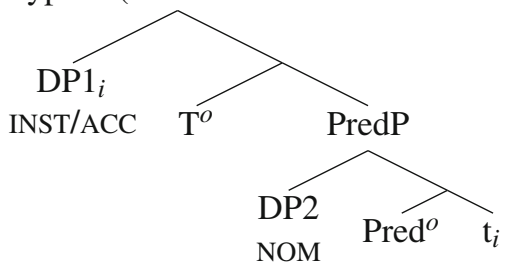

(66) Specification in Danish and English

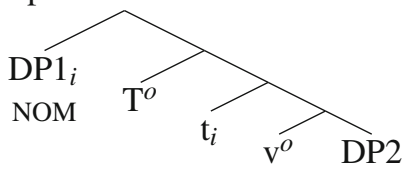

ACC

However, focusing on Swedish, I will argue that it cannot be the case that specification is derived simply by topicalising the predicate DP, as suggested by Heggie (1988) for English (see also Partee 1998 and Geist 2007 for versions of this analysis applied to Russian). On Heggie's account, DP2 is underlyingly the subject, in Spec,TP. The predicate DP then raises to Spec, $\mathrm{CP}$, accompanied by $\mathrm{V}$-to-C movement of the copula. As demonstrated by Heycock (1991, 186-189), Rothstein (2001, 259), and Mikkelsen (2004b, 2005), this analysis cannot be right for English, since it would predict the grammaticality of sentences like (67) — clearly not a well-formed sentence of English.

(67) English (Mikkelsen (2005), 8)

*The teacher might John be.

Mikkelsen (2004b) also argues convincingly against this kind of analysis for Danishwhich, unlike English, does have the requisite kind of predicate topicalization structures (main clause Verb Second [V2]). As we saw in (63) above, DP2 in Danish specificational sentences is marked with Accusative case. In topic-initial V2 clauses on the other hand, as shown in (68), DP2 is obligatorily marked with Nominative case. 
(68) Danish (Mikkelsen 2004b, 30)

Den højeste spiller på holdet er hun/*hende ikke. the tallest player on team.DEF is she.NOM/*her.ACC not

'She isn't the tallest player on the team.'

Indeed, the same is true also for predicate topicalizaton in Swedish.

(69) Swedish

Den längsta spelaren är jag/*mig inte (- men jag är en

the tallest player am I.NOM/*me.ACC not (- but I am a

duktig löpare).

good runner)

'I'm not the tallest player (- but I am a good runner).'

However, in Swedish (as in Dutch, Polish and Russian, but unlike in Danish and English), DP2 is obligatorily Nominative also in specificational clauses. This then leaves open the possibility that predicate topicalization might indeed be the correct analysis of specification in these languages.

However, there are a number of reasons for rejecting this analysis. As Mikkelsen (2004b) demonstrates for Danish, predicate topicalization and specificational sentences are structurally distinct. This is true also for Swedish. Here, I will focus on one of the several diagnostics used in Mikkelsen (2004b), namely the placement of negation and medial adverbs, such as 'inte' (not), which in Mainland Scandinavian are standardly assumed to occur at the left edge of $v \mathrm{P}^{41}$ Mikkelsen (2004b) shows that in specificational clauses, these elements obligatorily occur to the left of DP2 (70a), whereas in predicate topicalization sentences, they occur to the right of DP2 (70b). ${ }^{42}$

(70) Danish (Mikkelsen 2004b, 24)

a. Specification

Den højeste spiller på holdet er ikke Minna. the tallest player on team.DEF is not Minna

'The tallest player on the team isn't Minna.'

b. Predicate Topicalization

Den højeste spiller på holdet er Minna ikke.

the tallest player on team.DEF is Minna not

'Minna isn't the tallest player on the team.'

Mikkelsen (2004b) shows that this syntactic contrast is associated with a difference in meaning. As shown in (71), from Swedish (Mikkelsen 2004b gives similar examples

\footnotetext{
41 Several other of Mikkelsen's (2004b) tests used for Danish can be be used to show that specification and predicate topicalization are structurally distinct also in Swedish, for instance their distribution in sentences embedded under 'non-bridge' verbs.

42 See Mikkelsen (2004b, 26-27) for arguments that this contrast cannot be reduced to a difference between constituent negation vs. sentence negation.
} 
from Danish), NEG-DP2 order is only felicitous when DP2 is focused, i.e., when the sentence is assigned a specificational interpretation. ${ }^{43}$

(71) Swedish: Specification

Vem är den bästa spelaren i laget?

('Who's the best player on the team?')

[Focus set: Minna, Lisa, Anna]

a. Den bästa spelaren i laget är inte Minna (- det är

the best player on team.DEF is not Minna.FOC (- it is Lisa).

Lisa)

'The best player on the team isn't Minna (- it's Lisa).'

b. \#Den bästa spelaren i laget är Minna inte (- det

the best player on team.DEF is Minna.FOC not (- it är Lisa).

is Lisa)

'The best player on the team isn't Minna (- it's Lisa).'

Further, as illustrated by the contrast between the predicate topicalization sentence in (72) and the specificational sentence in (51a) above, in (51a), reference to DP1 is with the non-gendered pronoun 'det' (it), whereas in (72), reference to DP1 is with the gendered pronoun 'hon' (she).

(72) Swedish: Predicate Topicalization

Berätta något om Minna -

('Tell me something about Minna -')

[Focus set: good football player, fast runner, avid reader, keen hiker.]

a. Den bästa spelaren i laget är Minna inte (- men

the best player on team.DEF is Minna.TOP not (- but

nog kan hon löpa).

$A D V$ can she run)

'Minna isn't the best player on the team (- but she sure can run).'

b. \#Den bästa spelaren i laget är inte Minna (- men

the best player on team.DEF is not Minna.TOP (- but

nog kan hon löpa).

$A D V$ can she run)

'Minna isn't the best player on the team (- but she sure can run).'

It is also worth noting that predicate topicalization sentences in both Danish and Swedish differ from specificational sentences in terms of their word order in modal sentences, as shown with the Swedish examples in (73) (see Mikkelsen 2004b, 48 for Danish examples).

\footnotetext{
43 In the remainder of this section, I adopt Mikkelsen's convention of using the position of negation to distinguish between specification and predicate topicalization.
} 
(73) Swedish

a. Specification

Den längsta spelaren i laget kan då inte vara Minna the tallest player in team.DEF can ADV not be Minna-

det måste vara Lisa!

it must be Lisa

'The tallest player on the team can't be Minna - it must be Lisa!'

b. Predicate Topicalization

Den längsta spelaren i laget kan Minna då inte varathe tallest player in team.DEF can Minna ADV not be -

hon är ju bara $150 \mathrm{~cm}$.

she is ADV only $150 \mathrm{~cm}$

'Minna can't be the tallest player on the team - she's only $150 \mathrm{~cm}$ tall.'

Hence, as shown by Mikkelsen (2004b) for Danish, we find that Swedish has both predicate topicalization and specification, and that these are different from each other, both in terms of their syntactic, semantic, and information structural properties.

To summarise this section, Swedish specificational copular sentences are characterised by the following facts:

(74) i. DP2 is the subject, marked with Nominative case;

ii. DP1 pronominalises like a predicate/property;

iii. Word order is [DP1 MOD NEG COP DP2];

iv. DP2 is obligatorily focused, and DP1 is a topic.

Additionally, in relation to the first observation, we also saw evidence from Dutch, Polish and Russian (which behave otherwise like Swedish), that agreement in these languages is with DP2. Moreover, in relation to the second observation, we saw evidence from Polish and Russian that DP1 allows both Nominative and Instrumental case, depending on whether it is interpreted as an individual or stage level predicate.

For Danish, Mikkelsen (2004b) concludes that DP1 in specification is a predicative (non-referential) subject. For Swedish, as for Polish, Russian, and Dutch, however, this analysis cannot be right, given that in these languages, unlike in Danish and English, DP2 is the subject (and in Polish and Russian, DP1 shows the Nominative-Instrumental case alternation).

The basic structure proposed for Swedish specification is given in (65) above. However, implementing this kind of analysis is not uncomplicated. I have shown that a predicate topicalization analysis (à la Heggie 1988) is not viable. A different theoretical alternative comes from Heycock (2012), building on Romero (2005), who argues that specification is a type of inverted equation-in both types of languages discussed here (her focus is on the contrast between DP1 and DP2 agreement). She posits the structure in (75) as underlying both specificational and uninverted equatives, where the two arguments differ in terms of intentionality. 
(75) Heycock $(2012,231)$

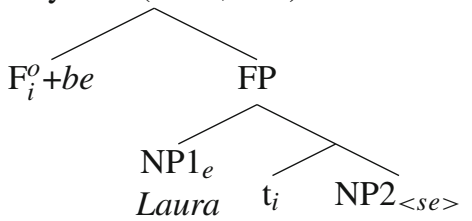

the winner

She argues that since the functional head $\mathrm{F}^{o}$ raises to merge with the copula, the two DPs end up in a small clause configuration, such that both DPs become eligible for movement to the specifier of the copula. In specificational clauses, this will be the type $<s e>\mathrm{DP}(\mathrm{NP} 2)$, whereas in regular equatives, it is the type $e$ DP (NP1) that moves. (For further details, I refer the reader to Heycock 2012.)

Although an appealing option, it is not clear how this account would handle the fact that, in languages of the Swedish type, the case on DP1 (NP2 in (75)) in specificational sentences alternates along the same semantic dimension as DP2 in predicational and equative sentences. While this does not amount to a flat-out refutation of Heycock's account, it seems like her account would at least need to be modified along the lines sketched in $(38) /(65)$ to accommodate this fact. Of course, a problem for the movement analysis of Nominative DP2 in specificational sentences is the observation from Sect. 2, that such DPs cannot undergo A-bar movement. This (along with the binding facts) was one of the major empirical points motivating the bi-clausal analysis for equation and individual level predication (38). This raises the question of why this DP should be eligible for inversion in specificational sentences with predicate Nominative case, as in (53)-(57).

I propose that specificational sentences involve a low FocP. DP2 (the grammatical subject and an individual of type $e$ ) then enters into an Agree relation with both $\mathrm{T}^{o}$ and $\mathrm{Foc}^{\circ}$ in its base-position, thereby receiving Nominative case and becoming marked as an obligatorily focused constituent. It then moves to Spec,FocP where it becomes 'criterially frozen' (having valued all of its features), and is no longer eligible for further movement (see Rizzi 2006, 2016). The (Nominative or Accusative/Instrumental) predicate (see (65)) then moves to Spec,TP, in order to satisfy the EPP-feature on $\mathrm{T}^{o}$. (76) illustrates:

(76) Specification: Swedish type (final version)

a. Type I (Nominative DP1)

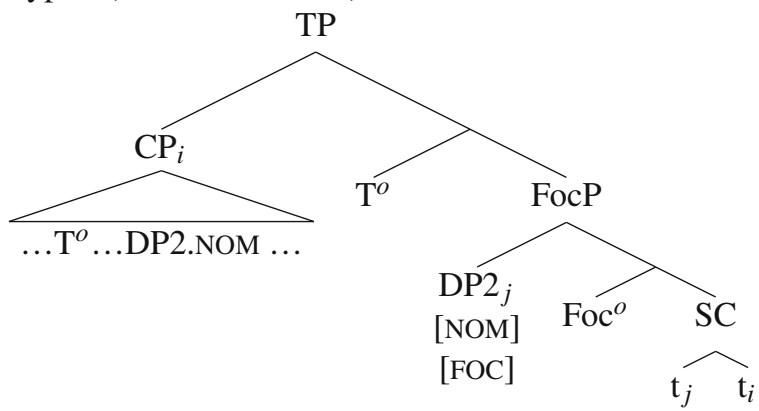


b. Type II (Instrumental/Accusative DP1)

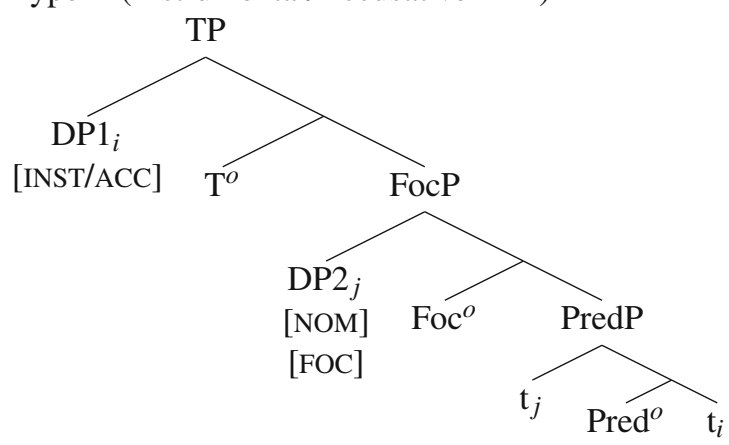

More can, and should, no doubt be said about specification in these types of languages, in particular regarding the semantic composition. A corollary of the current proposal is that DP1 must move as a predicate and leave a higher type trace, in order for the composition to work out. I take this to be a desirable consequence, given that DP1 in these sentences is interpreted as a property with a variable slot, to get valued by the individual denoted by DP2. While the details of the syntax-semantics mapping remain to be worked out in more detail, the analysis proposed here has the benefit of capturing both the word order and the information structural properties of specificational sentences, as well as the interpretation of specification as involving property containing a variable slot, which gets valued by the individual denoted by the postcopular DP.

\section{Conclusion}

The first goal of this paper was to show that the Swedish case-alternation, given the associated interpretive and distributional facts, must be an LF phenomenon (contra Sigurðsson 2006). I then presented comparative data, primarily from Polish, but also from English, Danish, Dutch and Russian, showing (i) that the Swedish alternation is sensitive to the same types of semantic factors that condition the choice of predicate case in Polish, Russian and Dutch, and (ii) that the Swedish alternation also shares syntactic properties with copular sentences in these languages, regarding movement and binding. I suggested that the morphological and semantic contrasts are mediated by the same structural difference, proposing a biclausal analysis for Nominative case, and a monoclausal analysis for Accusative/Instrumental case. I also pointed to a typological generalisation regarding the way that the syntax mediates interpretation, whereby Swedish copular sentences follow the same strategies as in Polish, Russian and Dutch, which are different from those in English and Danish. I further showed that this typological split runs deeper. Adding to the work by Mikkelsen (2002, 2004a, b, 2005, 2011); Geist (2007); Partee (2010); Heycock (2012), and others, I demonstrated that also specifiational copular sentences in Swedish pattern with those in the former group of languages, and unlike those in the latter-thus making the generalization one about how syntax and information structure mediate interpretation. This then echoes the view articulated in Partee $(2010,44)$ whereby "one language may have an information-structure-motivated diathesis choice where another language 
uses information-structure alone.” Regarding specification, I argued that the data supports a particular type of predicate inversion analysis, whereby specificational copular sentences are derived from the same kinds of structures underlying predicational and equative sentences.

Acknowledgements I am grateful to Julie Anne Legate, Florian Schwarz, Luke Adamson, Alexandros Kalomiros, Milena Šereikaité, and Mark-Matthias Zymla, as well as audiences at the University of Pennsylvania, GLAC 22, CamCoS5, and MACSIM 6, for helpful comments and feedback. Thanks also to Jim Wood and the anonymous reviewers for helpful suggestions. Many thanks also to my consultants, Zuzanna Fuchs, Iga Nowicz, Kamil Popielarz, Ola Gogłoza, and Michał Przykucki, Frida Nilsson, Hannah Diverde, Kicki Djärv, and Robert Djärv, Ava Creemers, Nikita Bezrukov, and Rune Nyrup. The Swedish data is also informed by my own native speaker's intuitions. All data is my own unless otherwise stated, and all errors are, of course, my own.

Funding Open Access funding enabled and organized by Projekt DEAL.

Open Access This article is licensed under a Creative Commons Attribution 4.0 International License, which permits use, sharing, adaptation, distribution and reproduction in any medium or format, as long as you give appropriate credit to the original author(s) and the source, provide a link to the Creative Commons licence, and indicate if changes were made. The images or other third party material in this article are included in the article's Creative Commons licence, unless indicated otherwise in a credit line to the material. If material is not included in the article's Creative Commons licence and your intended use is not permitted by statutory regulation or exceeds the permitted use, you will need to obtain permission directly from the copyright holder. To view a copy of this licence, visit http://creativecommons.org/licenses/by/4.0/.

\section{References}

Adger, David, and Gillian Ramchand. 2003. Predication and equation. Linguistic Inquiry 34 (3): 325-359. Antonenko, Andrei. 2010. Puzzles of Russian subjunctives. In University of Pennsylvania working papers in linguistics, ed. Jon Scott Stevens, Vol. 16, 1-10.

Babyonyshev, Maria, and Ora Matushansky. 2006. Back to the past. In Formal approaches to Slavic linguistics 14: The Princeton meeting, ed. James Lavine, Steven Franks, Mila Tasseva-Kurktchieva, and Hana Filip, 17-34. Ann Arbor, Michigan: Michigan Slavic Publications.

Bailyn, John Frederick. 2001. The syntax of Slavic predicate case. In ZAS papers in linguistics 22, ed. Katarzyna Dziwirek, Herbert S. Coats, and Cynthia Vakareliyska. Ann Arbor, Michigan: Michigan Slavic Publications.

Bailyn, John Frederick. 2002. Overt Predicators. Journal of Slavic Linguistics 10.

Bailyn, John Frederick, and Barbara Citko. 1999. Case and agreement in Slavic predicates. In Formal approaches to Slavic linguistics 7: The Seattle meeting, ed. Katarzyna Dziwirek, Herbert S. Coats, and Cynthia M. Vakareliyska. Ann Arbor, Michigan: Michigan Slavic Publications.

Bailyn, John Frederick, and Edward J. Rubin. 1991. The unification of instrumental case assignment in Russian. In Cornell working papers in linguistics 9, eds. Almeida J. Toribio and Wayne E. Harbert. Ithaca, New York: Department of Modern Languages and Linguistics, Cornell University.

Bhatt, Rajesh, and Shoichi Takahashi. 2011. Reduced and unreduced phrasal comparatives. Natural Language \& Linguistic Theory 29 (3): 581-620.

Bondaruk, Anna. 2014. Polish equatives as symmetrical structures. In Advances in the syntax of DPs: Structure, agreement, and case. Linguistik Aktuell/Linguistics Today. Vol. 217, eds. Anna Bondaruk, Gréte Dalmi, and Alexander Grosu, 61-94. Amsterdam: John Benjamins Publishing Company.

Bowers, John. 1993. The syntax of predication. Linguistic inquiry 24 (4): 591-656.

Caponigro, Ivano. 2003. Free not to ask: On the semantics of free relatives and wh-words cross-linguistically. PhD dissertation, University of California, Los Angeles.

Carlson, Gregory Norman. 1977. Reference to kinds in English. PhD dissertation, University of Massachusetts, Amherst. 
Chomsky, Noam. 2000. Minimalist inquiries: The framework (MITOPL 15). In Step by step: Essays on minimalist syntax in honor of Howard Lasnik, eds. Roger Martin, Davida Michaels, Juan Uriagereka, and Samuel Jay Keyser, 89-155. Cambridge, MA: MIT press.

Chomsky, Noam. 2001. Derivation by phase. In Ken Hale: A life in language, ed. Michael Kenstowicz, 1-52. Cambridge, MA: MIT press.

Chomsky, Noam, and Howard Lasnik. 1977. Filters and control. Linguistic Inquiry 8 (3): 425-504.

Citko, Barbara. 2008. Small clauses reconsidered: Not so small and not all alike. Lingua 118 (3): 261-295.

Comorovski, Ileana. 2007. Constituent questions and the copula of specification. In Existence: Semantics and syntax, ed. Ileana Comorovski, and Klaus von Heusinger, 49-77. Dordrecht: Springer.

Corver, Norbert, and Winfried Lechner. 2014. Comparative Deletion and Comparative Subdeletion. draft.

Deal, Amy Rose. 2009. The origin and content of expletives: Evidence from "selection". Syntax 12 (4): 285-323.

den Dikken, Marcel. 2006. Relators and linkers. the syntax of predication, predicate inversion, and copulas. Cambridge, MA: The MIT Press.

Doron, Edit. 1983. Verbless predicates in Hebrew. PhD dissertation, The University of Texas at Austin.

Eid, Mushira. 1983. The copula function of pronouns. Lingua 59: 197-207.

Geist, Ljudmila. 2007. Predication and equation in copular sentences: Russian vs. English. In Existence: Semantics and syntax, eds. Ileana Comorovski and Klaus von Heusinger, 79-105. Dordrecht: Springer.

Giorgi, Alessandra, and Fabio Pianesi. 1997. Tense and aspect: From semantics to morphosyntax. Oxford studies in comparative syntax. Oxford, UK: Oxford University Press.

Hartmann, Jutta, and Caroline Heycock. 2017. Variation in copular agreement in Insular Scandinavian. In Syntactic variation in Insular Scandinavian (Studies in Germanic linguistics 1), eds. Höskuldur Thráinsson, Caroline Heycock, Hjalmar P. Petersen, and Zakaris Svabo Hansen, 234-275. Amsterdam, The Netherlands: John Benjamins Publishing Company.

Heggie, Lorie. 1988. The syntax of copular structures. PhD dissertation, University of Southern California.

Heycock, Caroline. 1991. Layers of predication: The non-lexical syntax of clauses. PhD dissertation, University of Pennsylvania, Philadelphia, PA.

Heycock, Caroline. 2012. Specification, equation, and agreement in copular sentences. The Canadian Journal of Linguistics/La revue canadienne de linguistique 57 (2): 209-240.

Heycock, Caroline, and Anthony Kroch. 1999. Pseudocleft connectedness: Implications for the LF interface level. Linguistic Inquiry 30 (3): 365-397.

Heycock, Caroline, and Anthony Kroch. 2002. Topic, focus, and syntactic representations. In Proceedings of the 21 st West Coast conference on formal linguistics, eds. Line Mikkelsen and Christopher Potts, 101-125. Somerville, MA: Cascadilla Press.

Higginbotham, James. 1985. On semantics. Linguistic Inquiry 16 (4): 547-593.

Higginbotham, James. 1987. Indefiniteness and predication. In The representation of (in)definiteness, eds. Eric Reuland and Alice GB ter Meulen, 43-70. Cambridge, MA: MIT Press.

Higgins, Roger Francis. 1973/1979. The pseudo-cleft construction in English. New York: Garland.

Hiraiwa, Ken. 2002. Multiple Agree. Paper presented at the 25th GLOW Workshop: Tools in Linguistic Theory.

Jacobson, Pauline. 1995. On the quantificational force of English free relatives. In Quantification in natural language, ed. Emmon Bach, Eloise Jelinek, Angelika Kratzer, and Barbara Partee, 451-486. Dordrecht: Kluwer.

Kroch, Anthony. 1989. Reflexes of grammar in patterns of language change. Journal of Language Variation and Change 1: 199-244.

Kroch, Anthony. 1994. Morphosyntactic variation. In Proceedings of the 30th annual meeting of the Chicago Linguistics Society, eds. Katharine Beals, Jeannette Denton, and Robert Knippen. Chicago: Chicago Linguistic Society.

Kusumoto, Kiyomi. 1999. Tense in embedded contexts. PhD dissertation, University of Massachusetts Amherst.

Lechner, Winfried. 2001. Reduced and phrasal comparatives. Natural Language \& Linguistic Theory 19 (4): 683-735.

Legate, Julie Anne. 2008. Morphological and abstract case. Linguistic Inquiry 39 (1): 55-101.

Legate, Julie Anne. 2014. Voice and v: Lessons from Acehnese. Linguistic inquiry monographs, vol. 69. Cambridge, MA: MIT Press. 
Link, Godehard. 1983. The logical analysis of plural and mass terms: A lattice-theoretical approach. In Meaning, use, and interpretation of language, ed. Rainer Bäuerle, Christoph Schwarze, and Arnim von Stechow, 302-323. Berlin: Walter de Gruyter.

Maling, Joan, and Rex A. Sprouse. 1995. Structural case, specifier-head relations, and the case of predicate NPs. In Studies in comparative Germanic syntax, ed. Hubert Haider, Susan Olsen, and Sten Vikner, 167-186. Dordrecht: Kluwer.

Marantz, Alec. 1991. Case and licensing. In Proceedings of ESCOL '91, eds. German Estphal, Benjamin Ao, and Hee Rakh Chae, 234-253. Cornell: Cornell Linguistics Club.

Matushansky, Ora. 2000. The instrument of inversion. Instrumental case and verb raising in the Russian copula. In Proceedings of the 19th West Coast conference on formal linguistics, eds. Roger BillereyMosier and Brook Danielle Lillehaugen, 101-115. Somerville: Cascadilla Press.

Matushansky, Ora. 2008. A case study of predication. In Studies in formal Slavic linguistics. Contributions from formal description of Slavic languages, eds. Franc Marušič and Rok Zaucer, Vol. 6.5, 213-239. Frankfurt am Main: Peter Lang.

Matushansky, Ora. 2010. Russian predicate case, encore. In Proceedings of FDSL 7.5., eds. Gerhild Zybatow, Philip Dudchuk, Serge Minor, and Ekaterina Pshehotskaya, 117-135. Frankfurt am Main: Peter Lang.

Matushansky, Ora. 2012. On the internal structure of case in Finno-Ugric small clauses. Finno-Ugric Languages and Linguistics 1 (1-2).

McFadden, Thomas. 2004. The position of morphological case in the derivation. PhD dissertation, University of Pennsylvania, Philadelphia, PA.

Mikkelsen, Line. 2002. Specification is not inverted predication. In Proceedings of North East Linguistics Society 32, ed. Masako Hirotani, 403-422. Amherst, MA: Graduate Linguistic Student Association (GLSA).

Mikkelsen, Line. 2004a. Specificational subjects - a formal characterization and some consequences. Acta Linguistica Hafniensia 36: 79-112.

Mikkelsen, Line. 2004b. Specifying who: On the structure, meaning, and use of specificational copular clauses. PhD dissertation, University of California, Santa Cruz, Santa Cruz, CA.

Mikkelsen, Line. 2005. Copular clauses. specification, predication and equation. Amsterdam: Benjamins.

Mikkelsen, Line. 2011. Copular clauses. Semantics: An international handbook of natural language meaning 2: 1805-1829. Chap. 68.

Moro, Andrea. 1997. The raising of predicates: Predicative noun phrases and the theory of clause structure. Cambridge: Cambridge University Press.

Padučeva, Elena Viktorovna, and Vladimir A. Uspenskij. 1997. Binominativnoe predloženie: Problema soglasovanija svjazki. Sbornik statej pamjati DI Šmeleva: Oblik slova.

Pancheva, Roumyana. 2006. Phrasal and clausal comparatives in Slavic. In Formal approaches to Slavic linguistics 14: The Princeton meeting, ed. James Lavine, Steven Franks, Mila Tasseva-Kurktchieva, and Hana Filip, 236-257. Ann Arbor, Michigan: Michigan Slavic Publications.

Pancheva, Roumyana. 2009. More students attended FASL than CONSOLE. In Formal approaches to Slavic linguistics 18: The Cornell meeting, ed. Wayles Browne, Adam Cooper, Alison Fisher, Esra Kesici, Nikola Predolac, and Draga Zec, 382-399. Ann Arbor, Michigan: Michigan Slavic Publications.

Partee, Barbara. 1985. Ambiguous pseudoclefts with unambiguous 'be'. In Proceedings of the North Eastern Linguistic Society 16, eds. Stephen Berman, Jae-Woong Choe, and Joyce McDonough, 354-366. Amherst, Massachusetts: GLSA (Graduate Linguistic Student Association) UMass/Amherst.

Partee, Barbara. 1986. Noun phrase interpretation and type-shifting principles. In Studies in Discourse Representation Theory and the theory of generalized quantifiers, ed. Jeroen Groenendijk, Dick de Jong, and Martin Stokhof, 115-143. Dordrecht: Foris.

Partee, Barbara. 1998. Copula inversion puzzles in English and Russian. In Formal approaches to Slavic linguistics 7: the Seattle meeting, ed. Katarzyna Dziwirek, Herbert Coats, and Cynthia M. Vakareliyska, 361-395. Ann Arbor, Michigan: Michigan Slavic Publications.

Partee, Barbara. 2010. Specificational copular sentences in Russian and English. In Oslo studies in language: Russian in contrast, ed. Atle Grønn, and Irena Marijanovic, 25-49. Oslo: University of Oslo.

Pereltsvaig, Asya. 2001. On the nature of intra-clausal relations. PhD dissertation, McGill University, Montreal, Canada.

Pesetsky, David, and Esther Torrego. 2004. Tense, case, and the nature of syntactic categories. In The syntax of time, ed. Jacqueline Guéron, and Jacqueline Lecarme. Cambridge, MA: MIT Press.

Preminger, Omer. 2014. Agreement and its failures, vol. 68. Cambridge, MA: MIT Press. 
Progovac, Ljiljana. 1993. Locality and subjunctive-like complements in serbo-croatian. Journal of Slavic linguistics 1 (1): 116-144.

Rapoport, Tova R. 1987. Copular, nominal and small clauses: A study of Israeli Hebrew. PhD dissertation, Massachusetts Institute of Technology.

Rezac, Milan. 2013. Case and licensing: Evidence from ECM+DOC. Linguistic Inquiry 44 (2): $299-319$.

Rizzi, Luigi. 2006. On the form of chains: Criterial positions and ECP effects. Current Studies in Linguistics Series 42: 97.

Rizzi, Luigi. 2016. "Further explanation" of cartographic properties: Interfaces, locality and labeling. Paper presented at the 5th Cambridge Comparative Syntax conference (CamCos5).

Romero, Maribel. 2005. Concealed questions and specificational subjects. Linguistics \& Philosophy 28: 687-737.

Rothstein, Robert A. 1986. Equation and ascription: The nominative/instrumental opposition in West Slavic. In Case in Slavic, eds. Richard Domenick Brecht and James Steven Levine, 312-322. Columbus, OH: Slavica.

Rothstein, Susan. 1995. Small clauses and copular constructions. In Small clauses, syntax and semantics, ed. Anna Cardinaletti, and Teresa Guasti, 27-48. New York: Academic Press.

Rothstein, Susan. 2001. Predicates and their subjects. Dordrecht: Kluwer.

Russell, Bertrand. 1919. Introduction to mathematical philosophy. London: Allen \& Unwin.

Saab, Andrés, and Nicolás Lo Guercio. 2020. No name: The allosemy view. Studia Linguistica 74 (1): 60-97.

Sigurðsson, Halldór Ármann. 2006. The nom/acc alternation in Germanic. In Comparative studies in Germanic syntax: From Afrikaans to Zurich German, ed. Jutta M. Hartmann, and László Molnárfi, 13-50. Amsterdam/Philadelphia: John Benjamins Publishing Company.

Sigurðsson, Halldór Ármann. 2012. Minimalist C/case. Linguistic Inquiry 43 (1): 191-227.

Sigurðsson, Halldór Ármann. 2013. Case in Swedish: A preliminary overview. Paper presented at the 25th Scandinavian Conference of Linguistics (SCL 25), Formal Ways of Analyzing Variation (FWAV) workshop, at Haáskóli Íslands (University of Iceland).

Vergnaud, Jean-Roger. 1977/2008. Letter to Noam Chomsky and Howard Lasnik on "Filters and Control," April 17, 1977. In Foundational issues in linguistic theory: Essays in honor of Jean-Roger Vergnaud, eds. Robert Freidin, Carlos Peregrín Otero, and Maria Luisa Zubizarreta, 3-17. Cambridge, MA: MIT Press.

Williams, Edwin. 1983. Semantic vs. syntactic categories. Linguistics and Philosophy 6: 423-446.

Williams, Edwin. 1994. Thematic structure in syntax. Linguistic inquiry monographs, vol. 23. Cambridge, MA: MIT press.

Yang, Charles. 2000. Internal and external forces in language change. Language Variation and Change 12 (3): 231-250.

Publisher's Note Springer Nature remains neutral with regard to jurisdictional claims in published maps and institutional affiliations. 